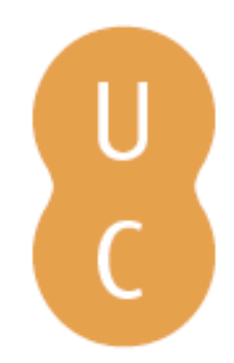

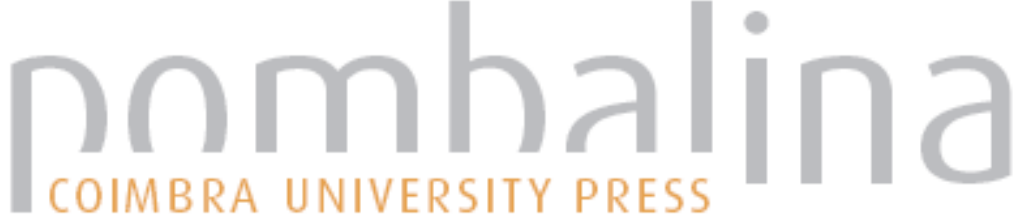

\section{«Lost in Translation»: the Hellenization of the Egyptian Tradition}

Autor(es): $\quad$ Sousa, Rogério

Edições Afrontamento; CITCEM - Centro de Investigação

Publicado por: $\begin{aligned} & \text { Transdisciplinar «Cultura, Espaço e Memória»; Centro de Estudos } \\ & \text { Clássicos e Humanísticos; Alexandria University; Imprensa da }\end{aligned}$ Universidade de Coimbra

URL persistente:

URI:http://hdl.handle.net/10316.2/36183

DOI:

DOI:http://dx.doi.org/10.14195/978-989-26-0966-9_17

Accessed : $\quad$ 26-Apr-2023 12:07:26

A navegação consulta e descarregamento dos títulos inseridos nas Bibliotecas Digitais UC Digitalis, UC Pombalina e UC Impactum, pressupõem a aceitação plena e sem reservas dos Termos e Condições de Uso destas Bibliotecas Digitais, disponíveis em https://digitalis.uc.pt/pt-pt/termos.

Conforme exposto nos referidos Termos e Condições de Uso, o descarregamento de títulos de acesso restrito requer uma licença válida de autorização devendo o utilizador aceder ao(s) documento(s) a partir de um endereço de IP da instituição detentora da supramencionada licença.

Ao utilizador é apenas permitido o descarregamento para uso pessoal, pelo que o emprego do(s) título(s) descarregado(s) para outro fim, designadamente comercial, carece de autorização do respetivo autor ou editor da obra.

Na medida em que todas as obras da UC Digitalis se encontram protegidas pelo Código do Direito de Autor e Direitos Conexos e demais legislação aplicável, toda a cópia, parcial ou total, deste documento, nos casos em que é legalmente admitida, deverá conter ou fazer-se acompanhar por este aviso. 


\title{
«LOST IN TRANSLATION»: \\ THE HELLENIZATION \\ OF THE EGYPTIAN TRADITION
}

\section{ROGÉRIO SOUSA}

Centro de Investigação Transdisciplinar Cultura, Espaço e Memória (University of Oporto).

\begin{abstract}
Starting with the guidelines that can help us to understand the framework of demotic culture during Greco-Roman Period this chapter is focused on the Egyptian background behind the multicultural tradition that rose in the Serapeum of Alexandria. Despite of its Hellenistic atmosphere, the Alexandrian Serapeum was the cradle of a new multicultural tradition: within its sacred precinct Greco-Egyptian deities received cult in the temple of Sarapis, while a multicultural community of scholars was actively engaged in the creation of a vast repertoire of texts and iconography. With its roots grounded on the Egyptian wisdom, such tradition was expressed in Greek or demotic philosophical discourses and was in use by a wide multicultural population, reaching so disparate territories as the Egyptian oasis of the Western Desert or the shores of the Atlantic.
\end{abstract}

For more than three thousand years, the Egyptian civilization developed a unique culture which, although firmly grounded on its Nilotic background, would have a bold impact, not only among its African neighbours, but also in some of the cultures of the Ancient Near East. And yet, with the exception of political propaganda, it seems that Egypt never aimed to seek an audience in what concerns cultural exchange with its neighbours. Acculturation of local populations apparently occurred massively in Nubia, but no particular efforts seem to have been made to adapt the Egyptian culture and cults to the Nubian population. On the contrary, the foundation of Egyptian temples on occupied territories underwent a massive and deep Egyptianization of Nubia, to such an extent that, in the 25th Dynasty, Nubian 
Pharaohs felt themselves entitled to remind the Egyptians of the «Egyptian» ways. As to the Asian neighbours, economic exchanges certainly led to the diffusion of Egyptian motifs, particularly as regards the use of Egyptian iconography in the decoration of objects. Nonetheless, the true Egyptianization seems restricted to the ruling elite: the children of the Asian city rulers were brought to Egypt to be educated in the royal kep itself in order to be instructed in the Egyptian culture, knowledge and literature ${ }^{1}$. In spite of the restricted target of this acculturation, it certainly played a very important role in the diffusion of Egyptian wisdom and religious literature in the Near East. It is a strong possibility that this phenomenon may have created intellectual circles outside the borders of Egypt that were familiar with Egyptian literature. Such cultural trend eventually led to the translation of the Egyptian texts themselves, a phenomenon particularly clear in Israel, where such translation seems to have been the result of the scholarly work of biblical writers and not so much the result of Egyptian scholars aiming to reach foreign audiences ${ }^{2}$.

\section{EGYPTIAN TRADITION IN NEW CONTEXT: THE ALEXANDRIAN MULTICULTURALISM}

Even according to contemporary definitions, Alexandrian society was fully multicultural: it «was at ease with the rich tapestry of human life and the desire amongst people to express their own identity in the manner they see fit» ${ }^{3}$. It is in this context that we assist, apparently for the first time, to a new cultural trend which consisted in the «translation» of the Egyptian tradition itself. Hellenistic language and culture was sought, in Greco-Roman Egypt, as a way to spread autochthonous ideas and cults to a foreign, wider audience.

It is with no surprise that we detect the first attempts of this cultural trend in the Hellenization of the iconography of the Egyptian gods. At the time of the Macedonian conquest, Memphis was the most important Egyptian city and, certainly for that reason, its local cult of Osirapis, a funerary manifestation of Apis, supposed to be the embodiment of the $\mathrm{Ba}$ (divine power) of Ptah, became the main source of inspiration for the new syncretic cult of Sarapis promoted by Ptolemy I. From then on, the once purely Egyptian deities manifested themselves with Hellenized names, such as Sarapis, Isis and Harpokrates (from the Egyptian Horpakhered, «Horus-the-child») and were fully rendered in Greek iconography ${ }^{4}$.

\footnotetext{
${ }^{1}$ SHAW (ed.), 2002: 245.

${ }^{2}$ The influence of Egyptian wisdom literature on biblical texts is detectable not only in the translation and adaptation of some of its texts but also in the influence of Egyptian in the Hebrew language. See SHUPAK, 1993: 348.

${ }^{3}$ BLOOR, 2010.

${ }^{4}$ Already in the Late Period, religious syncretism was as distinctive feature of Egyptian religion, which undoubtedly paved the way for the syncretic identification of Egyptian deities with Greek gods under Ptolemaic rule.
} 
Once clad with Greek identities, these deities were soon escorted by other GrecoEgyptian deities such as Agathodaimon (the Egyptian god Shay, «Fate») ${ }^{5}$, Hermanubis (resulting from the identification between Hermes and Anubis), Cerberus (the Greek guardian of the Hades equated with Anubis), Sirius (the star-goddess Sopdet) or Thermouthis (the Hellenized serpent-goddess Renenutet).

These cults not only resulted from a process of translation of the Egyptian tradition into Greek language and imagery, as they were the object of syncretic assimilation with Greek divinities as well. Without discarding the direct involvement of Egyptian priests in this «translation» process, still, it is a strong possibility that the Greeks themselves were actively involved as well. After all, Greek interest in the Egyptian gods is at least as old as the conquest of Egypt by Alexander. A temple of Isis at Piraeus is attested as early as the same year of the conquest of Egypt (332 B.C. $)^{6}$. Under Ptolemaic rule, however, these cults soon became the very expression of the multicultural character of Alexandria.

The interaction of Greek and Egyptian traditions was brilliantly used by the Ptolemaic kings to empower their political and religious status in ways that would be difficult to achieve if they followed the traditional Macedonian ideology alone. In fact, Hellenization of the Egyptian deities involved a reversed process of Egyptianization of Hellenistic rulers ${ }^{7}$. Alexander started this process by adopting the horns of Amun in his own iconography and by making himself depicted in Egyptian temples, such as in the Luxor Temple, with the typical pharaonic regalia. Macedonian kings and Roman emperors followed his example, particularly in the walls of the newly built Egyptian temples, depicting themselves as «true» Pharaohs. Through this Egyptianization, Macedonian rulers gained divine status and achieved a broader acclamation of their «universal» power. Thus, Alexandrian multiculturalism must always be understood at the light of the political ideology of the Ptolemaic kings who search for their own «universal» acclamation.

With this ideological purpose in mind, Alexandrian art increasingly blurred the frontiers between the Egyptian and the Greek style. Royal statues once again give us a number of different examples of this phenomenon with Ptolemaic kings and queens adopting the hieratic attitude and regalia of the Egyptian tradition, while displaying a fair naturalistic portrait. The once purely Egyptian deities were also the object of intriguing sculptures, displaying a subtle combination of the Greek canon of proportions with the Egyptian hieratic attitude. One of the finest statues of this kind was recently found in the sunken site of the ancient Pharos lighthouse and it depicts the goddess Isis who, in spite of the hieratic attitude and Egyptian dress, presents an unexpected dynamism wisely achieved by means of the «wet drapery» that reveals her sensual body magnificently recalling the myth of

\footnotetext{
${ }^{5}$ HORNUNG, BRYAN, 2007: 211.

${ }^{6}$ HORNUNG, 2001: 64.

${ }^{7}$ SALES, 2005: 52.
} 
Aphrodite born from the sea. Reversely, some Greek sculptures - while displaying the typically Praxitelean smoothness - present an outstanding sense of sacredness achieved with the «solarization» of the forms, usual in royal or divine Egyptian statues. With time this trend evolved significantly and gave rise to the production of pieces that displayed an even more complex and deeper symbiosis. Such is the group statue depicting Alexander Helios and Cleopatra Selene, the sons of Cleopatra and Antony: the twins are represented as the personifications of the Moon and the Sun depicted within the coils of two snakes. While the boy has a sun-disc on his head, the girl boasts a crescent and a lunar disc. Both discs are decorated with the wedjat-eye. This interesting composition mingles Egyptian symbols (wedjat-eye, the cobras and the side-lock of the boy) with the Greek representation of the sun and the moon as a couple (note that in Egypt the moon did not have a female connotation).

Even the dual identity of the Alexandrian deities themselves reflected this search for universalism. Mingling attributes borrowed from Ptah, Osiris, Amun, Zeus, Poseidon and Hades, the all-encompassing solar-chthonian god Zeus-Sarapis took his seat as cosmocrator, the supreme god of a truly multicultural Pantheon ${ }^{8}$. Isis reinforced her status of universal goddess, absorbing the qualities of Hathor and Nut, but also Demeter and Athena ${ }^{9}$, and soon enough she would be called «the one who is all» ${ }^{10}$. As to Harpokrates, being himself designated by many Hellenized names such as Harsiese (from the Egyptian name Horsaiset, «Horus son of Isis»), or Harendotes (from the Egyptian form Hornedjitef, «Horus the savior of his father»), was also the object of syncretic identification with the Greek Herakles, sometimes depicted wearing the typical mace of this mythic hero ${ }^{11}$. Not surprisingly, in this syncretic process of "translation» and assimilation, the former Egyptian deities gained the status of truly universal gods. The newly founded Alexandrian cults - either divine or royal - were thus generating the culture cement that could bring together the multicultural population of Alexandria under the universal sovereignty of the Ptolemaic kings.

Furthermore, textual evidence, such as the famous Rosetta Stone or the Canopus Decree, fully documents a «bilingual» culture and society and may be seen as the very symbol of Alexandrian Hellenism. However, this «bilinguism» was not only the result of a sociological reality: either in texts or in iconography, Alexandrian «bilinguism» always expresses the search for universalism.

If nowadays it is difficult to have a clear idea of how deep multiculturalism was imprinted in the buildings of ancient Alexandria, its necropoleis provide a vivid glimpse on such cultural «bilinguism». It should be noted that, particularly in the funerary realm, such approach between the Greek and the Egyptian traditions was almost impossible to achieve,

\footnotetext{
${ }^{8}$ WITT, 1997: 53.

${ }^{9}$ Even outside Egypt, the cult of Isis was rapidly associated with the Greek cults of Athena and Demeter as it is showcased in the Iseum of Dion in Macedonia.

${ }^{10}$ HORNUNG, 2001: 64. See also in this respect the article of Mona Haggag, supra in this volume.

${ }^{11}$ CORTEGGIANI, 1986: 176.
} 
given the profound differences that separated their conceptions of the afterlife ${ }^{12}$. The arriving Hellenistic settlers brought with them their own traditions of funerary monuments and rituals, usually involving cremation or urn burials. Such burials can be found in Alexandria with cinerary urns placed in loculi, rather than the corpse ${ }^{13}$. Sometimes it is possible to detect in the same tomb the use of cremation and inhumation, some of the latter with mummified bodies ${ }^{14}$. Curiously enough, in a land where burning of the corpse was considered the ultimate punishment, new funerary practices were rapidly adopted merging both Classical and Egyptian traditions ${ }^{15}$.

The catacombs of Kom el-Shogafa are famous for its hybrid style of the decoration showcasing the diffusion of Egyptian iconographical elements in Alexandrian tombs ${ }^{16}$. In this respect, a secondary group of tombs positioned around the so-called «Hall of Caracalla» presents particularly interesting features for our discussion. From the cloister of eight rock-cut tombs, only two (tombs 1 and 2) still display some of the original decoration painted on the white stuccoed walls. These tombs date back to the Roman occupation (late 1 st century or early 2 nd century A.D.) and each wall is divided in two registers. Those from the upper register are depicted in Egyptian style, whereas those from the lower register are depicted in pure Greek style. The surviving features of their iconographic program are similar, although presumably executed by different artists ${ }^{17}$.

In the upper register, the central wall features the typical embalming scene of Osiris (Fig. 1): the god lies on a bed while Anubis performs the funerary rites before Isis and Nephthys, who protect the mummy of Osiris with their wings. Horus stands behind the two goddesses. The left wall depicts Thoth standing before an enthroned Osiris, while the right wall presents the resurrection of Osiris depicted in standing position between two enthroned deities.

The lower register is decorated with scenes related to the myth of Persephone. In the central wall, Hades is depicted on his chariot, taking Persephone in his arms while Artemis, Athena and Aphrodite watch the event (Fig. 1). In the left wall, Persephone rests in a luxurious garden with flowers, sources, nymphs and a river-god. In the right wall (only the decoration of tomb 2 remains), Persephone is depicted coming out from the underworld in the cave of Eleusis, assisted by her mother Demeter (left), Hermes (center) and Hecate (right) ${ }^{18}$.

\footnotetext{
${ }^{12}$ Seemingly such Egyptianization can be detected in the theme of the weighing of the heart, already in Homer. See RODRIGUES, 2006: 247-258.

${ }^{13}$ Tomb BI at Gabbari presents a vast number of loculi some of which held both cremations and inhumations. DODSON, IKRAM, 2008: XXVIII.

${ }^{14}$ Tomb BI at Gabbari. DODSON, IKRAM, 2008: XXVIII.

${ }^{15}$ DODSON, IKRAM, 2008: 292-293.

${ }^{16}$ VENIT, 2002: 124-145. See also in this volume the article of Kyriakos Savvopoulos.

${ }^{17}$ GUIMIER-SORBERTS, 1998: 34-37.

${ }^{18}$ GUIMIER-SORBERTS, 1998: 34-37.
} 


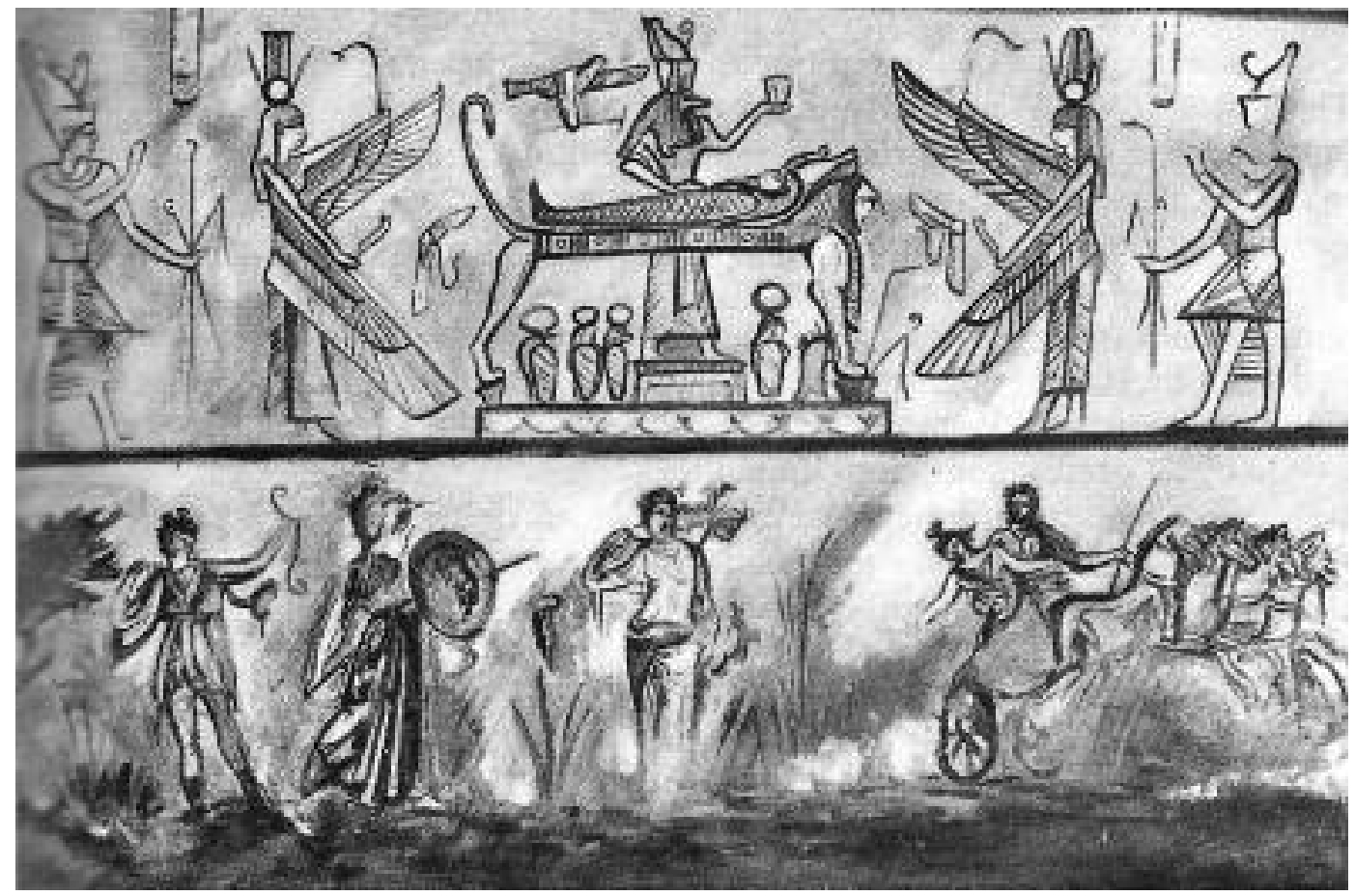

Fig. 1: Kom el-Shogafa, Hall of Caracalla, tomb 2, central wall.

Such program clearly documents that the hybrid Greek-Egyptian style displayed in most of the tombs of Alexandria was not merely a question of fashion. It shows that the myths of Osiris and Persephone were being taken as parallel mythic cycles, both expressing the idea of resurrection. We could say that, at the level of iconography, these tombs display the same bilingual culture that created the Rosetta Stone. However, an important distinction must be made: while the official Ptolemaic documents merely looked for an equality of status, the «bilingual» tombs of Kom el-Shogafa attest a deeper inquiry. In other words, it is clear that in Roman Alexandria both traditions became the object of a search for meaning, perhaps looking for an universal interpretation of their myths, thus attesting that the search for universalism was no longer just a matter of political ideology and fully become a distinctive feature of the Alexandrian culture.

\section{THE EGYPTIAN NECROPOLEIS IN GRECO-ROMAN PERIOD}

The Hellenization of the Egyptian tradition, merging both Classical and Egyptian motifs, did not remain restricted to Alexandria. This process started immediately in the context of the Egyptian necropoleis themselves, where tomb decoration, extremely rare in 

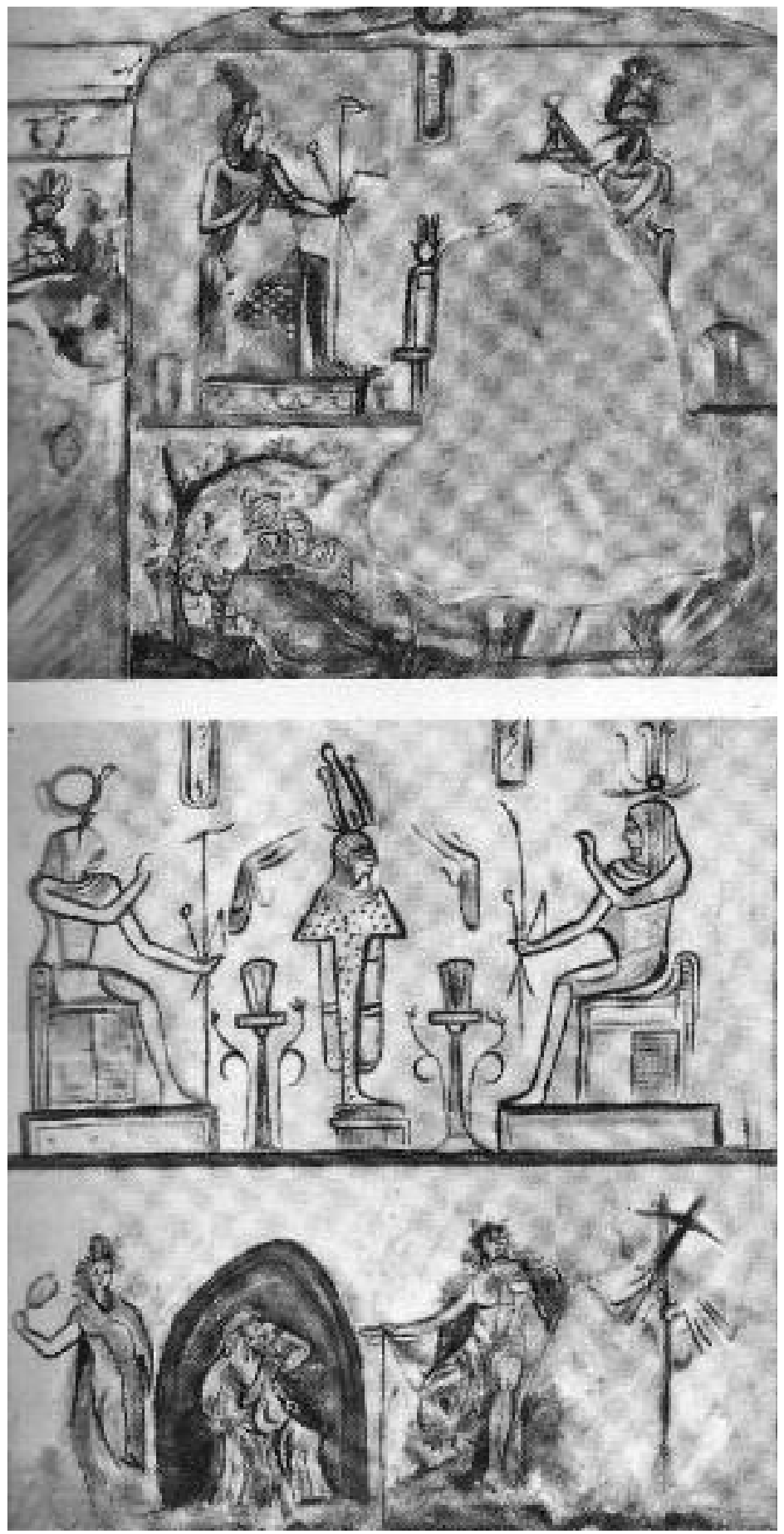

Fig. 2a: Kom el-Shogafa, Hall of Caracalla, tomb 1 (left wall) and tomb 2 (rigth wall). 


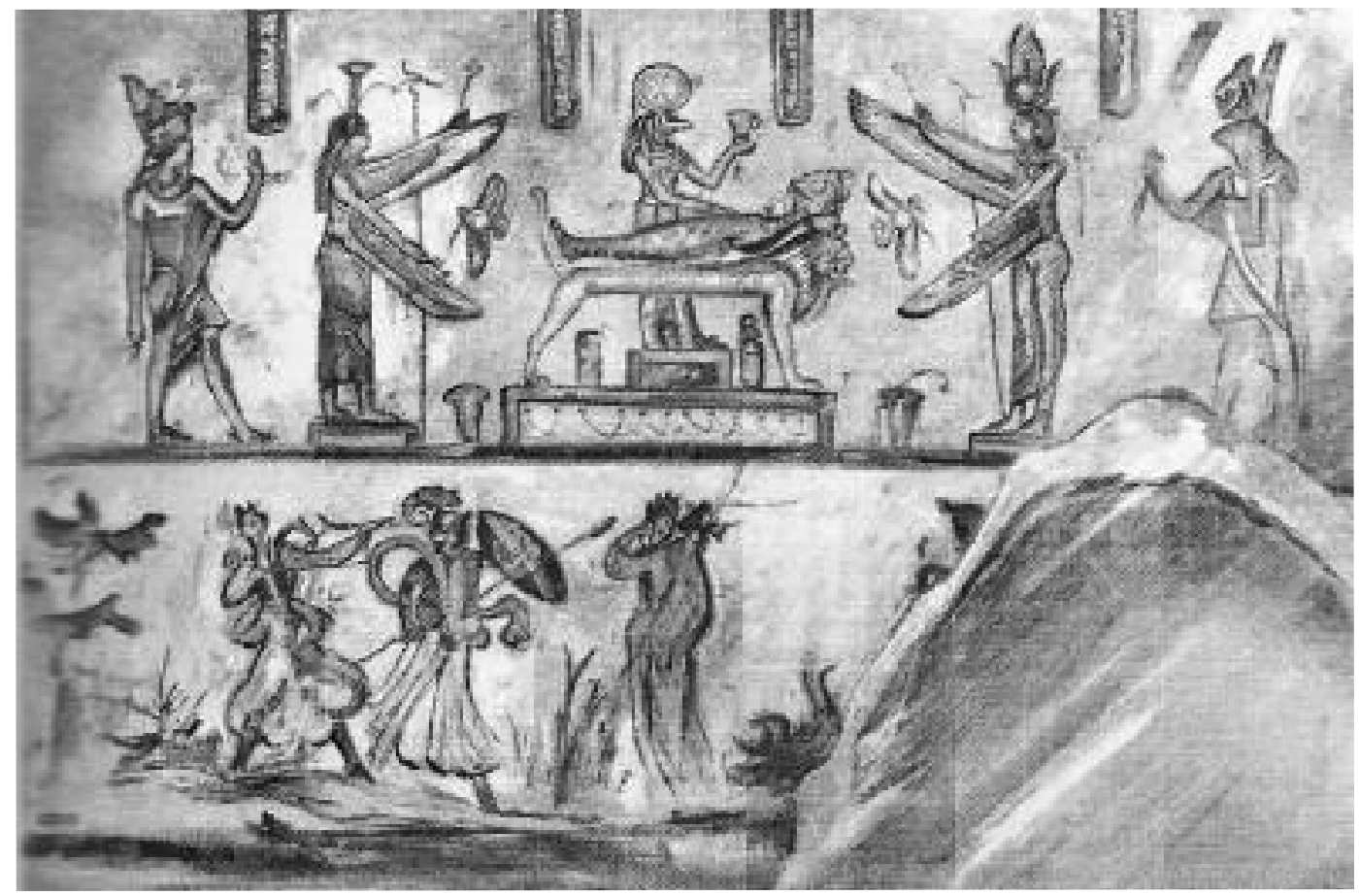

Fig. 2b: Kom el-Shogafa, Hall of Caracalla, tomb 1, central wall.

Ptolemaic Egypt, also displays such an erudite combination of Egyptian and Hellenistic features, as it is the case of the rock-cut tomb of Siamon (Siwa oasis) dating from the early Ptolemaic times, where the deceased, depicted in Greek fashion, participates in the Egyptian funerary rites, such as the Opening-of-the-mouth ritual, or in the traditional scenes of the afterlife, such as the weighing of the heart.

In fact, interest in syncretic approaches can be detected in Egyptian sources from the very beginning of Macedonian occupation. The most remarkable example in this respect is the tomb of Petosiris, high priest of Thoth under Ptolemy I (in Tuna el-Gebel). The tomb chapel is designed as a temple, presenting two styles of decoration. The pronaos of the tomb is decorated with the Egyptian mundane themes related to the activities of the daily life, but the human figures are depicted in Greek clothing and attitudes, while in the inner room the decoration is purely Egyptian style and it is exclusively devoted to religious and sacred motifs ${ }^{19}$. Although mingling the Greek and Egyptian styles, we detected in the tomb of Petosiris a veiled tension between the two traditions: while a strong sense of sacredness is associated with the Egyptian style, the Greek fashion is somehow diminished and publicly

${ }^{19}$ BAGNALL, RATHBONE, 2004: 167. 
«mocked» by its identification with peasants and shepherds, the lowest social stratum of the Egyptian society.

This particular trend of «syncretism» was short lived: in Ptolemaic times, monumental tombs decorated in Egyptian style fall in disuse, due to a profound change of patterns in the use of Egyptian necropoleis. The reuse of earlier sepulchers for collective burials is now the rule, sometimes with addition of new chambers provided with the typical individual loculi of Greco-Roman tombs. In some regions, such as in the Fayum, mummies apparently remained for considerable periods among the living, perhaps housed inside a wooden shrine kept at home or in a public repository. Periodically these bodies were removed to the necropolis but not to be buried in an individual or family tomb but to be piled together in mass brick-lined burial pits ${ }^{20}$.

Burial practices also underwent a process of profound change with the evergrowing importance of collective burials and cheaper mummification techniques which, for the first time in ancient Egypt, originated a true democratization of the necropoleis, a phenomenon in which the Hellenistic element seems to have played a decisive role since, against the usual practice, Greeks and Romans settlers did search for mummification ${ }^{21}$. The disparate use of mummification by the Greek and the Roman elite is one of the most striking phenomena of cultural «contamination» of the Hellenic population by Egyptian burial practices. However, while adopting mummification, the new settlers also transformed it: the attention of the embalmers shifted from the preservation of the corpse itself to its external appearance: it is not uncommon that beautiful wrappings hide crude and inferior procedures of preservation of the corpse ${ }^{22}$.

It is not surely coincidental that with the Greek era the development of cartonnage adornments of the mummy has been greatly expanded. Beautifully painted collars, pectorals or mummy-masks were fixed to the mummy, usually showcasing traditional Egyptian motifs such as the four Sons of Horus, Anubis, winged goddesses and sacred scarabs producing a colourful and beautiful effect suitable for public display before burial. In the mummy-masks it is worthy to note the depiction of curly hair over the forehead of the deceased, a typical Hellenistic motif introduced in royal portraits since the Ptolemaic Period $^{23}$. While the decoration of the masks tends to observe the Egyptian idealized style, mummy-masks and portraits become progressively more naturalistic thus suggesting a stronger attachment to the everyday existence than before. Many of these masks show the deceased in Greek garments with Egyptian motifs relegate to subordinate positions $s^{24}$. The Greek or Roman elements, such as hairstyle, short beard or clothing, seem to be included

\footnotetext{
${ }^{20}$ DODSON, IKRAM, 2008: 297.

${ }^{21}$ TAYLOR, 2001: 87.

${ }^{22}$ TAYLOR, 2001: 91.

${ }^{23}$ WILDUNG, REITER, ZORN, 2010: 179. IKRAM, DODSON: 1998: 187-188.

${ }^{24}$ TAYLOR, 2001: 243.
} 
in the funerary equipment in order to display the high rank of the deceased and may not be related at all to his ethnic identity. The Greek element thus became omnipresent in the autochthonous necropoleis.

The opposite process also occurred with Egyptian motifs integrated into typically Greek funerary materials. In Terenouthis (Kom Abu Billo) were found carved stelae dating from the late 1 st to early $3 \mathrm{rd}$ centuries A.D. These gravestones represent the deceased, clad in Greek garments, with hands raised in worship (as an orans) or reclining at a banquet, perhaps their own funerary banquet. Besides the inscription with the name and date of death of the deceased, iconography often includes Egyptian features such as architectonic elements and gods (especially in their animal form) ${ }^{25}$.

Eventually, these processes evolved to the full manifestation of a multicultural identity. Funerary shrouds dating from the Roman Period, present a full combination of the complex and multicultural set of ideas and artistic styles that coexisted in Greco-Roman Egypt. The deceased, depicted at the center of the shroud, wears a Hellenistic garment and his depiction is naturalistic, following the style of the Roman portraits - such as it occurs in the contemporary «Fayum portraits». At his left side figures the jackal-headed god Anubis and at his right side stands Osiris (depicted as an Egyptian mummy but in full frontal view). At the background, small depictions include mummification and judgment scenes typical of the Egyptian funerary tradition. Most significantly, the deceased holds a papyrus scroll or a bunch of flowers, suggesting his identification either with a Greek Philosopher (papyrus scroll) or with a justified Osiris (bunch of flowers). Shrouds like these fully attest that a fully multicultural identity was achieved, at least in the realm of the funerary beliefs ${ }^{26}$.

The local funerary traditions thus document the magnitude of multiculturalism in later Egypt. It should be noted that such processes occurred quite naturally and didn't necessarily require the adoption of non-Egyptian features. It could manifest itself simply in the way how pharaonic tradition was adopted and adapted for contemporary use. Anthropoid coffins, for example, fell progressively out of use: mummies of the Greco-Roman Period relied on the elaboration of their wrappings and cartonnage equipment turning the anthropoid coffins obsolete ${ }^{27}$. Sarcophagi, on the other hand, were still being used, although seldom for an individual: more often they were used as shrines or "pavilions» for the public display of mummies, according to «evidence that mummies remained for some time accessible to the living before consignment to the necropolis $\aleph^{28}$. Even religious beliefs were under revision: for the first time, female anthropoid coffins of Ptolemaic or early Roman times

\footnotetext{
${ }^{25}$ BAGNALL, RATHBONE: 2008: 81.

${ }^{26}$ MÁLEK, 2003: 356.

${ }^{27}$ IKRAM, DODSON: 1998: 241.

${ }^{28}$ IKRAM, DODSON: 1998: 273.
} 
describe the deified female deceased as «Hathor», as opposed to the traditional male title «Osiris» always used as a funerary title both for men and women ${ }^{29}$.

The patterns of use of the necropolis were changing: now it was no longer confined to the funerary use and more and more it was becoming a public space, we almost could see it as a funerary «forum» or «agora», where very popular cults took place. The animal cults, already important in the Late Period, attracted to the necropoleis a multitude of pilgrims from Egypt and the Mediterranean that visited their renowned oracles, such as occurred in the Serapeum at Saqqara ${ }^{30}$. Deified sages were also the object of very popular cults as healing deities, such as the cult of Imhotep (equated with Asklepius) in the Asklepeum in Saqqara and, together with Amenhotep son of Hapu, in the former funerary temple of Hatshepsut at Deir el-Bahari (Thebes). Surprisingly enough Greek «prophets» were allowed to live and work in the oracles of the Egyptian necropoleis. During the 2nd century B.C. we know that Ptolemaios, a son of a Macedonian general, lived in Saqqara in the vicinity of the temple devoted to the Canaanite goddess Astarte. There he worked as a dream interpreter in the sanatorium of the Asklepeum, the temple of the deified Imhotep ${ }^{31}$. Also found at Saqqara, a painted limestone trade sign, now in Cairo Egyptian Museum (27567) presents the image of an Apis bull and a Greek inscription: "At the god's command I interpret dreams. Good fortune. The interpreter is a Cretan ${ }^{32}$. Apparently, Greek dream interpreters were favored in Egyptian oracles, perhaps due to the health of Greek customers.

Egyptian necropoleis thus reveal that multiculturalism did not manifest exclusively in the changes detected in the production of the funerary artifacts or in the design of tombs. It deeply affected local traditions which, in turn, were also open to new inputs and absorbed influences selectively showcasing vivid interest on innovative features, as has it always occurred in Pharaonic Egypt ${ }^{33}$. As a consequence of the new demographic influx, the use of Egyptian necropoleis was now deeply contaminated by Hellenistic social patterns. Multiculturalism was now a distinctive feature of Egyptian funerary practices.

\section{EGYPTIAN TEMPLES \\ IN GRECO-ROMAN PERIOD}

Temples of the Ptolemaic and Roman times are the result of an extensive temple building program, probably initiated by the Egyptian priests themselves ${ }^{34}$. All over Egypt temples were built or expanded, such as the temples of Hathor at Dendera, Khnum at Esna,

\footnotetext{
${ }^{29}$ Such is the case of the coffins from Akhmim. WALKER, HIGGS, 2001: 109.

${ }^{30}$ TAYLOR, 2001: 255.

${ }^{31}$ CHAVEAU, 2000: 130-140.

32 BAGNALL, RATHBONE, 2004: 91.

${ }^{33}$ SOUSA, 2011c: 131-150.

${ }^{34}$ FINNESTAD, 1997: 185.
} 
Horus at Edfu, Sobek and Horus at Kom Ombo and Isis at Philae. Although apparently conforming to the Egyptian tradition, the late temples clearly display a renovation of the «classical» model. Sacred precincts present a number of architectonic distinctive features, such as the typical screen wall of the pronaos, or the conception of the innermost sanctuary as an independent structure erected within the main building and, last but not the least, the so-called «birth houses» erected in the vicinity of the main temple ${ }^{35}$.

Nevertheless, the most distinctive feature of the new style of temples is its decoration. The walls of these temples are heavily decorated with texts and iconography and they can be seen as huge reservoirs of the Egyptian knowledge. The texts carved on the walls are apparently extracts from the collection of books kept in the temple archives, and they are representative of the entire spectrum of ancient Egyptian religion and scholarly learning. Monumental inscriptions refer to rituals and myths but also to calendars, astronomy or medical tools. Later temples are literally the translation of temple's knowledge into architecture and through them cultic knowledge preserved in books could be transformed into action through the appropriate rites ${ }^{36}$.

In fact, temples of Greco-Roman Egypt are all about knowledge. It would be difficult to see in this renovation of the Egyptian temples some kind of influence by the Greek occupants. And yet, in spite of the royal support ${ }^{37}$, they fully represent a reaction towards the Greek culture.

As a local reservoir of the Pharaonic knowledge, each temple literally "petrified» the local tradition into a complex set of buildings. Certainly this role was reflected in the importance of sacred books as well. In each temple, a local selection of sacred books was enshrined in a small library that codified the entire treasury of relevant knowledge for that particular community ${ }^{38}$. The sacred libraries of Edfu and el-Tod still display a catalogue of the books they hold. These catalogues reckon 42 books in each temple and correspond to a local canon intending to represent the universe in book form ${ }^{39}$. Obviously they do not reflect the entire corpus of texts available in the «Per Ankh» or the House of Life - the school and the library of the temple - which was certainly much more extensive $e^{40}$. The scribes and scholars of the House of Life were called by the Greeks hierogrammateis. Some

\footnotetext{
${ }^{35}$ FINNESTAD, 1997: 185.

${ }^{36}$ ASSMANN, 2002: 419.

37 The Ptolemies followed a dual policy toward the great Egyptian temples. On the one hand, the temples political and economic power was decisively curtailed. On the other hand, the Ptolemies supported the extensive program of building and rebuilding Egyptian temples. FINNESTAD, 1997: 233.

${ }^{38}$ ASSMANN, 2002: 412.

${ }^{39}$ Mirroring the 42 provinces of Egypt, the canon of 42 books described in the reliefs of the sacred libraries reflects the desire of self-segregation and canonization. Forty-two was in fact allusive to the 42 nomes of Egypt, thus suggesting the identification between the books and the world. ASSMANN, 2002: 413.

${ }^{40}$ Therefore we should distinguish the sacred libraries (positioned inside the temple) from the archives of the House of Life (positioned in a separate building probably used also as a school).
} 
were priests, all were guardians of liturgical and other kinds of texts, coping and commenting on them, but were also involved in the administration and management of temple's properties. They worked in temple annexes that housed the libraries and served as places of studying and writing ${ }^{41}$. This community had his own way of life characterized by asceticism and contemplation, forming what can be seen as a «textual community» ${ }^{42}$.

Late Egyptian temples were certainly not isolated from the rest of the society. However, while most of the sectors of the Egyptian society revealed a notorious openness to the Hellenistic element, in the context of the Egyptian temples the response to foreign occupation took form in the tendency toward self-segregation. The development of cryptography is precisely a distinctive feature of the intellectual culture of later Egyptian temples. The result was the exponential growth of the repertory of signs with almost every religious center developing its own cryptic system ${ }^{43}$.

In spite of the desire for self-segregation, the temples of later Egypt were important socioreligious forums for exchanging religious beliefs among large numbers of people, and of course the frequent temple festivals became lively meeting places for the population of neighbouring towns. Popular devotional activities took place around the temple, often assisted by priests. Many people came specifically for dream interpretations or oracles. Others visited, often from great distances, to seek medical help at those temples reputed to be centers of healing. Within the precincts of Hathor's temple at Dendera there was a sanatorium with baths and probably also facilities for healing incubation. Oddly enough, such devices are typical of the sanatoria from the Hellenistic sacred precincts (Epidauros), thus revealing an unexpected Greek «contamination» of the Egyptian temples ${ }^{44}$.

This «contamination» shows that even inside the sacredness of the temple's precinct, other intellectual forces were at work. In our view, the source for this trend could not be other than the House of Life.

Egyptian temples of Greco-Roman Period housed complex multidimensional communities which were simultaneously involved in the retrograde search for the «right» knowledge and in the prospective transformation and recreation of the temple, i.e., the «world». These two tendencies reflected in two cultural trends. One, enclosed within the secrecy of ritual practices, involved a centripetal phenomenon of self-segregation and manifested itself in a canon of texts kept secret in the sacred library of the temple. The other, centrifuge in nature, grew up in the open and broader context of the «House of Life» and was open to the influxes of the (multicultural) community that surrounded the temple.

\footnotetext{
${ }^{41}$ FINNESTAD, 1997: 228.

${ }^{42}$ ASSMANN, 2002: 418.

${ }^{43}$ ASSMANN, 2002: 418.

${ }^{44}$ FINNESTAD, 1997: 236.
} 
These two literary trends were always active in Egyptian religion and can be assigned respectively to the cult activities in stricto sensu (ritual and magical texts) and to the wisdom tradition (theological texts) ${ }^{45}$. As a reflex of this «dual» definition of the Egyptian religion, its Hellenization must be seen as a dual process as well: one based on ritual knowledge of the sacred libraries of the temple and the other grounded on the theological texts of the House of Life.

\section{THE EGYPTIAN CONNECTION: DEMOTIC
CULTURE IN THE GRECO-ROMAN PERIOD}

In close association to the Hellenization of the Egyptian intellectual tradition is its own «demotization». This process is again better illustrated in the funerary context. Perhaps as a result of the new cultural influxes detected in local necropoleis, changes deeply affected the funerary literature. During the second half of the Ptolemaic Period, there was a significant decline in the production of the Book of the Dead manuscripts, while other funerary compositions rose in production - such as the Documents of Breathing and the Book of Traversing Eternity. The reasons for this decline are difficult to grasp but it is possible that purchasers preferred their Netherworld guides to be written in contemporary demotic language, which of course originated less sacred artifacts than if written with hieroglyphic or even hieratic scripture. Yet, these demotic objects were preferred and regarded by customers as more useful, since they could understand them ${ }^{46}$. The adoption of the Documents of Breathing thus supposes not only a different social organization of the necropoleis ${ }^{47}$ but a new intellectual trend that aimed to expressed itself in a living language rather than a sacred but unintelligible script.

It is worthy to note that during Greco-Roman Egypt, scribes were using four different writing systems: demotic and Greek for everyday purposes, and hieroglyphic and hieratic for religious purposes. Only erudite scholars could understand the Egyptian language cyphred both in the hieroglyphic and hieratic writing ${ }^{48}$. Demotic, on the contrary, must be seen as the priviledged interface for the cultural interaction between Pharaonic tradition and Hellenism. In fact, ordinary scribes used demotic and Greek.

In the Egyptian temples some of the priests knew Greek and maintained contact with Greek scholars. Egyptian tradition in the Ptolemaic Period was vigorous and in full dialogue with much of the Hellenistic thought ${ }^{49}$. We have to keep in mind that, legendary or

\footnotetext{
${ }^{45}$ ASSMANN, 2001: 3-7.

${ }^{46}$ MUNRO, 2010: 59.

${ }^{47}$ Because they were written in demotic, it is also possible that these texts could have been copied without a formal supervision of professional priests or a temple: they could have been handed down simply by scribes working in the necropolis.

${ }^{48}$ ASSMANN, 2002: 414-415.

${ }^{49}$ FINNESTAD, 1997: 228.
} 
not, contact with Greek scholars begun long before the conquest of Alexander, thus originating the appearance of Egyptian motives in Greek texts, such as it occurred in Plato's or in Herodotus's writings. After the Macedonian invasion, however, Ptolemaic rulers actively encouraged the composition of scholarly works devoted to the Egyptian tradition, such as the historiographical work by Manetho, a priest of the temple of Re in Heliopolis, which constitutes a remarkable example of this new cultural trend. Although commissioned by Ptolemy II, such work can be properly considered as one of the first native attempts to translate autochthonous Egyptian tradition to a highly receptive Hellenistic audience. It is to be noted that such translation required the work of an indigenous scholar knowledgeable in the pharaonic tradition and learned in Greek language as well, and - most certainly - well acquainted with Greek historical literature, such as Herodotus's writings ${ }^{50}$. Egyptian scholars thus become active in the construction of a new civilization that aimed to reach universalism by means of its bilingual culture.

This same period witnessed to the increasing production of naturalistic «portraits» of sages: aging men displaying high social status and severe dignity. Some of them stand among the most accomplished sculptural works of Egyptian Art, depicting men with bold heads, hieratic attitude and clad with a long garment typical of the priests. These «wise men» present a very naturalistic rendering of the anatomical structure of the face and head, also displaying vivid "psychological» portraits. One could think of Hellenistic influence in the anatomical representation of aging men but such naturalism is also detected in purely Egyptian sculpture ${ }^{51}$. This is perhaps one of the most extraordinary corpus of Egyptian sculpture and surely reflects the important role performed by «sages» in Ptolemaic Egypt ${ }^{52}$.

This veneration for the wise men extended to and perhaps was inspired by the deification of the sages of the past. We have already mentioned the popularity and boldness of the cults of Imhotep and Amenhotep son of Hapu. This veneration is well documented in Egyptian demotic literature where sages from the past became the heroes of tales. These tales tell us that the special status of these men is specifically due to their knowledge on the sacred texts. In the demotic Story of Setne Khaemwas (Khaemwas was son of Ramses II and high priest of Ptah at Memphis,) the hero searches for a divine book written by Thoth «with his own hand». The book had the power to reveal «how it is possible by one magic formula

\footnotetext{
${ }^{50}$ See supra in this volume, the article of Luís Manuel de Araújo.

${ }^{51}$ This naturalistic trend is detected as far as the $4^{\text {th }}$ Dynasty in the royal statues of Menkhaure, but also in private statues, such as the bust of Ankhaf. Naturalistic royal portraits were also produced in the $12^{\text {th }}$ Dynasty, especially under Senuseret III and Amenemhat III and in the $18^{\text {th }}$ Dynasty, during the reign of Akhenaten, with special emphasis to the famous head of Nefertiti or Queen Tiy. See WILDUNG, REITER, ZORN, 2010: 84. The later example is particularly interesting for our discussion since it showcases the face of a «wised» woman who has grown old.

${ }^{52}$ MÁLEK, 2003: 347. This type of statues were also carved with pure Hellenistic portraits, such as it occurs in the statue of Hor, priest of Thoth (see WALKER, HIGGS, 2001: 182-183), where the influence of Roman portraiture seems to have been very skillfully merged with the Egyptian sculptural tradition giving.
} 
to enchant the sky, the earth, and the infernal regions, the mountains and the seas, to understand the language of the birds and reptiles, and then by a second formula to recover one's own identity» ${ }^{53}$. The search for knowledge thus reflects, in the demotic tradition, the quest for magical power, both contained and revealed by the sacred books.

The attribution of the authorship of the sacred books to Thoth is proverbial in ancient Egyptian literature and it can be traced back as far as the Middle Kingdom. In the tale Khufu and the Magicians, the great magician Djedi is supposed to be gifted with great magical power because «he knows the number of the secret chambers of the sanctuary of Thoth. Now the majesty of King Khufu had been spending time searching for the secret chambers of the sanctuary of Thoth in order to copy them for his temple» ${ }^{54}$.

The search for secret texts related to Thoth is a traditional motif of the Egyptian literature and it can be found in funerary texts, as well. Several chapters of the Book of the Dead were supposedly «miraculously» found by the prince Djedefhor, son of the king Khufu (4th Dynasty), also taken as a great magician, at the feet of a statue of Thoth, or in a secret chamber of his temple in Hermopolis ${ }^{55}$.

Written in demotic, the Book of Thoth reveals a later development of this intellectual trend. It was probably written in the 1st century A.D. ${ }^{56}$. Thoth imparts information regarding the netherworld, ethics, the sacred geography of Egypt, secret language and mysteries. Most interestingly, the text displays many correspondences with the Hermetica ${ }^{57}$. Such demotic text was clearly written by Egyptian priests, using Egyptian language to express their own tradition and, yet, it reveals knowledge akin to the hermetic tradition, which is traditionally considered a purely Hellenistic product.

Although the influence of Egyptian tradition in Hermetic texts has been greatly overlooked $^{58}$, today, however, it is acknowledged that hermetic texts made use of genuine Egyptian knowledge ${ }^{59}$. The Corpus Hermeticum comprises 18 Greek treatises and the Latin Asklepius, dating back from the 1 st to late 3 rd century A.D. Some of these texts are of a theological-philosophical nature, while others comprise magical, astrological or alchemical content ${ }^{60}$. In spite of the massive destruction of Hellenistic texts, we can still have a glimpse nowadays on what once must have been an immense literary corpus. When we consider

\footnotetext{
${ }^{53}$ This tale is written in a demotic papyrus found at Thebes in the tomb of a Coptic monk. It is dated from the Ptolemaic Period. See SALEH, SOUROUZIAN, 1987: nº 262.

${ }^{54}$ LICHTHEIM, 1975: 118

${ }^{55}$ See rubrics of chapter 30-b and chapter 64 of the Book of the Dead.

${ }^{56}$ JASNOW, ZAUZICH, 2005: 68

${ }^{57}$ HORNUNG, 2001: 48.

${ }^{58}$ Festugière greatly contributed to strengthen this idea, highlighting the predominance of Greek philosophical elements and reducing Egyptian influence to merely decorative motifs. EBELING, 2007: 9.

${ }^{59}$ However, the genuinely Egyptian concepts of the Hermetic tractates have been stressed after the discovery of the manuscripts of Nag Hammadi. EBELING, 2007: 30.

${ }^{60}$ EBELING, 2007: 9.
} 
the hermetic texts found in the library of Nag Hammadi, it becomes clear that such texts document the existence of an intellectual tradition that expressed itself in demotic, Greek ${ }^{61}$ and Coptic $^{62}$, with the texts from the Corpus Hermeticum as its later product. As the new findings suggest the Hermetica were not an isolated corpus and must be seen in a broader cultural perspective. For commodity, although they are usually used exclusively to designate the texts from the Hermetica, we will keep the Modern designations of «hermetic texts» or «Hermeticism», while referring to this broader multicultural intellectual trend highly dependent on the native demotic tradition, keeping in mind that such designations were not in use in Antiquity.

The content of the hermetic texts is heterogeneous and, in spite of the Hellenistic atmosphere, it can be traced back to traditional Egyptian motifs. It is clear that the Asklepius and its apocalyptic prophecy is a later product of pure Egyptian tradition that began with the Admonitions of Ipuwer, the Prophecy of Neferti and similar texts from the Middle Kingdom ${ }^{63}$. This literary tradition continued on to the Ptolemaic Period with texts such as the Nectanebo's Tale, the Demotic Chronicle, the Prophecy of the Lamb or the Oracle of the Potter. Compositions such as the Asklepius suggest a strong Hellenized context, which perhaps, even in the 3rd century, could only have been possible in Alexandria.

However, autochthonous cultural centres should have played an important role in the creation of such tradition. The Memphite temple of Ptah was perhaps one of the most likely contexts for the development of such demotic intellectual tradition ${ }^{64}$. This could explain many of the key features of hermetic theory, starting with Hermes Trismegistus himself. In fact, in the Hermetica, Trismegistus does not emerge as a god, but as a Philosopher instead, a supersage mixing the features of Plato, Moses and, above all, the deified Egyptian sage Imhotep (c. 2650 B.C.) who lived under the reign of Djoser Netjererkhet and performed such important tasks as the king's chief physician, high priest of Heliopolis and builder of the first pyramid ever erected in Egypt, the Stepped Pyramid at Saqqara. In later times, Imhotep was not only believed to be the founder of Egyptian wisdom and regarded as the very prototype of the sage, but also, from the 26th Dynasty onwards, he became a god in his own right. In Ptolemaic times, he was equated with the Greek god Asklepius and received cult as a healing deity. Finally, in the hermetic texts Hermes Trismegistus figures as a deified Philosopher, resulting from the Hellenization of the Egyptian cult of Imhotep. On the other hand his name fully displays his hybrid origin: he combines the Greek god Hermes with Thoth's epithet, «three times great», thus fully embodying the multicultural archetype of sacred wisdom - both Greek and Egyptian.

\footnotetext{
${ }^{61}$ This is the case of the Hermetica.

${ }^{62}$ A significant number of hermetic texts found in Nag Hammadi, some of them belonging to the Corpus Hermeticum, were also written in demotic and Coptic.

${ }^{63}$ HORNUNG, 2001: 51.

${ }^{64}$ LLOYD, 2002: 414.
} 
Although grounded on a demotic tradition, the Hermetica, as we know them, present Egyptian content fully expressed in a philosophical discourse, which in itself is a Greek innovation. Hence, such texts could only have been the result of a close cooperation between Greek philosophers deeply akin to Egyptian tradition and Hellenized Egyptian scholars. The Alexandrian Serapeum emerges again as the melting pot for the development and blooming of this multicultural intellectual trend.

\section{THE ALEXANDRIAN SERAPEUM AND THE CREATION OF A «UNIVERSAL» TRADITION}

As we already mentioned, Alexandrian gods attained the status of universal deities. Regardless of its origin, the universal character of Sarapis is usually seen as the result of the syncretic assimilation of several supreme gods as Hades, Zeus, Osiris and Helios. Nevertheless the characterization of Sarapis presents a much better correspondence with the divine definition of one particular Egyptian god, Ptah. Conspicuously overlooked by scholars, Ptah presents all the aspects of the divine definition of the Alexandrian deity and it was surely in this god that Sarapis found his archetypes. As a chthonian god, Ptah was a god of the underworld and as such he was the provider of the people of Egypt. The god presided over the fertility of the land and the growth of vegetation - one of his epithets was exactly the «Granary of Tatenen». His chthonian character gave him power over minerals that provided rich materials as stones and metals. But, above all, Ptah was the supreme god, creator of all living things but also a funerary deity with Osirapis as his manifestation. In spite of his chthonian definition, this supreme god also gained solar connotations when he became equated with Shu - the Heliopolitan god of light and divine utterance. As early as the New Kingdom, Ptah fully achieved the status of a supreme deity, thus paving the way for the proclamation of Sarapis as cosmocrator, the universal deity gifted with solar and chthonian attributes ${ }^{65}$.

The foundation of the cult of Sarapis occurred between the reigns of Ptolemy I and II, between 285 and 282 B.C. The earliest dedication found at the site of the Alexandrian Serapeum dates back to the reign of Ptolemy II, with the formal sanctuary being dedicated under Ptolemy $\mathrm{III}^{66}$. When a fire destroyed the temple in 181 A.D., it was rebuilt (by 217 A.D.) on a still larger scale ${ }^{67}$.

The great Serapeum of Alexandria was one of the most important monuments of ancient Alexandria, with its imposing buildings dominating the acropolis of the city. In the

\footnotetext{
${ }^{65}$ SOUSA, 2011b: 168-172.

${ }^{66}$ Tacitus (Histories 4.84) states that Ptolemy III was responsible for the dedication of the cult statue in Alexandria, since he financed the building stages of the main temenos and temple. WALKER, HIGGS, 2001: 73.

${ }^{67}$ BAGNALL, RATHBONE, 2004: 60.
} 
Roman times two monumental staircases led to the sacred precinct. Columned porticoes elegantly framed the sacred precinct, displaying fine and exquisite decoration, which included selected artworks both from the Greek world and Egypt, making this complex renowned through the Roman Empire as one of the most splendid places on earth.

Inside the main temple stood the famous chryselephantine statue of the god by the Athenian sculptor Bryaxis. Ptolemaic iconography of the god included a lotus-crown, beard and carefully divided fringe. It is only later in the Roman Period that the god is shown with a modius (corn-measure representing the importance of Egyptian corn to the feeding of the people of Rome $)^{68}$ on his head and is accompanied by Cerberus, the three-headed dog gatekeeper of the underworld ${ }^{69}$. In the Ptolemaic temple Sarapis was depicted enthroned - as the statue of Zeus at Olympia, perhaps holding a cornucopia or a sceptre - but sources from Roman times suggest that the statue of Sarapis depicted the god in standing position holding a staff and a cornucopia ${ }^{70}$.

The iconography of the god included a subtle feature, seldom noted: his lips are depicted open, as if speaking, probably alluding to his oracular reputation, as opposed to the Hellenistic iconography of Harpokrates - who raises his finger before the lips to impose silence in face of the mystery. The statues of Sarapis are meant to «speak» thus illustrating the recreation of the world with his divine utterance - like Ptah, who created the world with his Tongue.

Not to be overlooked are the underground galleries excavated within the area of the sacred precinct. As Kyriakos Savvopoulos and Robert Bianchi accurately point out, these galleries should not be taken as premises for the Library Daughter, as it is so often repeated $^{71}$. It is a possibility that some of them could have been used as catacombs for sacred animals thus replicating the chthonic passages of the Serapeum at Saqqara. A square pit excavated in the western side of the temple gave access to the northern underground galleries. One of these galleries was probably used as a crypt for the cult of Apis. It was excavated beneath the Temple of Sarapis itself and it held a black diorite statue representing Sarapis in his Apis bull incarnation with the sun-disk between his horns; an inscription dates it to the reign of Hadrian (117-38).

However, at least some of these galleries may have been used for the celebration of the mysteries of Sarapis as well. Echoes of these rituals have been handed down to us by written sources, such as the Asinus Aureus, but glimpses on the death and resurrection of Sarapis

\footnotetext{
${ }^{68}$ Note that, already in the Shabaka Stone, Ptah is referred to as the corn-provider of Egypt (Shabaka Stone, 61). See SOUSA, 2011b: 67.

${ }^{69}$ WALKER, HIGGS, 2001: 73.

70 The statue of Sarapis found in Cortina (Crete), was probably a copy of the Alexandrian statue. The same composition is reproduced in the Roman coins from the reign of Trajan. See BAKHOUM, 1995: 63. It may refer either to a new statue of Sarapis in the Serapeum or to another statue of the god that received cult in Alexandria.

${ }^{71}$ SAVVOPOULOS, BIANCHI, 2012: 56.
} 
can also be observed in Hadrian's Serapeum at Villa Hadriana where it was recreated in the statuary group that once decorated its inner rooms: here again figures the Apis bull along with the deified Antinoo - here identified with the reborn sun.

South to the Temple of Sarapis was excavated an imposing L-shaped underground passage that seems to have been used for such rituals. The underground galleries lead to a puzzling structure: a platform rising from a large basin excavated right in the central area of the court, probably working as a sacred lake. Resembling to the crypts of the Osireum in Abydos - also provided with a L-shaped underground passage giving access to a ritual island - this structure probably replicated in the Serapeum the chamber for the resurrection of the god. For this reason, this «island» figure as the most suitable place for the erection of the most of the Pharaonica found at the site ${ }^{72}$, such as monumental diorite scarab, depicting the rebirth of the sun $\operatorname{god}^{73}$.

Besides the cultic facilities, the Serapeum was composed of a complex of buildings displayed around the central court. In the great central court stood, already in Roman times, the Diocletian Column (the so-called Pompey Column), on top of which probably stood a statue of Sarapis-Helios. The column stood in front of a large lustral basin used for purification rituals. It was probably in the porticoes displayed around the central court that it was installed the library (the «daughter» of the Great Library) provided with lecture rooms, and smaller shrines. Facilities for pilgrims, such as the sanatorium and rooms for incubation, were certainly associated with the complex, as well.

To our perspective, in spite of the Hellenistic atmosphere of this complex, the Alexandrian Serapeum was fully working as any other contemporary Egyptian temple: besides the temple itself, where the divine cult was performed, the sacred precinct involved a complex system of crypts, facilities for its library/school and premises for pilgrims. The main difference between the Serapeum and the Egyptian autochthonous temples was the multicultural nature of the former: within its sacred precinct Greco-Egyptian deities received cult, while a multicultural community of scholars associated to the «House of Life» (i.e. the LibraryDaughter) was undergoing the creation of an open multicultural wisdom tradition. With its roots grounded on the Egyptian demotic wisdom, such tradition was now expressed in Greek philosophical discourses.

\footnotetext{
72 The creation of a "pure» Egyptian temple in the context of the Roman Serapeum could have been created as the result of the «Egyptianization» of Alexandria and its sacred places apparently promoted under Roman rule. See SAVVOPOULOS, BIANCHI, 2012: 20-25.

${ }^{73}$ Such position of the sacred scarab is known from the sacred lake at Karnak. See SOUSA, 2007: 279-302.
} 


\section{HERMETICISM}

AS A MULTICULTURAL «PARADIGM»

Archaeological evidence suggests that Memphite priests were particularly connected with the Alexandrian Serapeum. Among these testimonies figure the statues of the Memphite priest Psentais, depicted in Egyptian style ${ }^{74}$ and the Shabaka Stone (716-702 B.C.). This remarkable inscription was originally erected in the sacred precinct of Ptah in Memphis, from where it was taken in Ptolemaic times in order to be sent to the Alexandrian Serapeum, a suitable place for such monumental «book».

The inscription of the Shabaka Stone was certainly regarded, already at that time, as a major work of autochthonous theological tradition. In order to estimate the impact of this composition in the Egyptian cultural milieu of Greco-Roman Period, we have to keep in mind both the boldness of the role of the temple of Ptah in later Egypt and the prestige of the text itself, which, already at that time, embodied the quintessence of Egyptian theological thought ${ }^{75}$.

Although we don't have any direct quotation of this Egyptian text from ancient authors, either Egyptian or Greek, the cosmogonic vision of the inscription written on the Shabaka Stone is strikingly akin to the gnostic character of Alexandrian philosophical thought:

Heart took shape in the form of Atum, Tongue took shape in the form of Atum. It is Ptah, the very great, who was given (life) to all the gods and their kaw through this heart and through this tongue ${ }^{76}$.

In this text, the Supreme Being is Ptah who conceived the world in his Heart (i.e. mind - suggesting a parallel with the Greek concept of the divine nous) and created it with his Tongue (i.e. word - thus with strong correspondence with the divine logos).

Thus heart and tongue rule over all limbs in accordance with the teaching that it is in every body and it is in every mouth of all gods, all men, all cattle, all creeping things, whatever lives, thinking whatever it wishes and commanding whatever it wishes. (...) Sight, hearing, breathing - they report to the heart, and it makes every understanding come forth. As to the tongue, it repeats what the heart has devised. Thus all the gods were born and his Ennead was completed. For every word of the god came about through what the heart devised and the tongue commanded ${ }^{7}$.

\footnotetext{
${ }^{74}$ See supra in this volume, the text of Kyriakos Savvopolus, note 343. See also SAVVOPOULUS, BIANCHI, 2012: 116.

${ }^{75}$ SOUSA, 2011b: 112-120.

${ }^{76}$ Shabaka Stone (55), in LICHTHEIM, 1975: 54.

${ }^{77}$ Shabaka Stone (55), in LICHTHEIM, 1975: 54.
} 
With this statement the ancient writer aims to suggest that all living creatures were shaped according to the same "plan» conceived in the heart, i.e. the mind or intellect, of the creator god. This is the basis for one of the most important key-features of Hermeticism: the equivalence between man, understood as the microcosmos, and the Universe, the macrocosmos ${ }^{78}$. Thanks to their divine source, all living creatures are related to the mind of the creator. Between men, in particular, justice is a matter of obedience to a natural law. One should do what is loved (by god):

Justice is done to him who does what is loved, and punishment to him who does what is hated. Thus life is given to the peaceful, death is given to the criminal' ${ }^{9}$.

Already in Shabaka Stone we detect the ontological bonds which tie the «individual intellect to the universal Intellect and, in this way, the individual self to the infinite or absolute Self» ${ }^{80}$. From this vision results a «hieroglyphic» perspective of the world: all existing things compose a living text, the cosmos, in which each being is the earthly embodiment of a divine idea or plan ${ }^{81}$. The world is literally understood as a book whose «hieroglyphs» are the very living beings created by god, himself:

He is Tatenen, who gave birth to the gods, and from whom every thing came forth, (...) thus is recognized and understood that he is the mightiest of the gods. Thus Ptah was satisfied after he had made all things and all divine words (lit.: hieroglyphs) ${ }^{82}$.

Moreover, man is invested with a special responsibility for he is able to create "hieroglyphs» in the world, thus completing by means of his work the great creation of Ptah. Such vision is absolutely clear in the hermetic texts as well. It is therefore a strong possibility that the Shabaka Stone was regarded by Alexandrian scholars as a «Tabula Smaragdina» avant la lettre and that a congruent literary corpus might have been taken as the bulk of their «translation» work either in demotic or in Greek.

It was probably in the multicultural context of the Serapeum that it became possible the creation and diffusion of Hermeticism, as «universal» tradition. The Library-Daughter of Alexandria must therefore be seen as a Hellenized «House of Life» of the Serapeum with Hermeticism as its multicultural, thus universal, intellectual tradition.

\footnotetext{
${ }^{78}$ According to Hermetic texts, the «first human was formed by Nous, the creator of the world. The man himself functioned as a creative demiurge». In HORNUNG, 2001: 52.

${ }^{79}$ Shabaka Stone (55), in LICHTHEIM, 1975: 54.

${ }^{80}$ FILORAMO, 1999: 139.

${ }^{81}$ SOUSA, 2011b: 99-103.

${ }^{82}$ Shabaka Stone (55), in LICHTHEIM, 1975: 55.
} 
One of the main problems raised by this hypothesis is the conspicuous absence of references to Sarapis in the hermetic texts. In spite of that, numerous references are made to Isis, Horus, Thoth (Tat) and Imhotep (Asklepius). The supreme god is always referred to as the Universal Intellect (nous) and not as a concrete manifestation of a particular god that received cult. Curiously enough, also in this respect the hermetic tradition follows the Egyptian wisdom tradition from the «Houses of Life» of the Pharaonic temples. Although omnipresent in these texts, the identity of the supreme god is always left open, referring to the supreme god as an unnamed deity. The reason to left open the identity of the supreme god would be again the sake for universalism: as any other Egyptian wisdom tradition, Hermeticism was not restricted to a specific cult or temple ${ }^{83}$.

As we have mentioned, the characterization of the supreme god in the Hermetica presents a striking correspondence with the divine definition of Ptah in the Egyptian theological texts. With this equivalence in mind, we should thus question ourselves if the supreme god that received cult in the Serapeum could have any parallel with the Memphite creator god.

In fact, Ptah presents all the aspects of the divine definition of Sarapis. As a chthonian god, Ptah was a god of the underworld and as such he was the provider of the people of Egypt. The god presided over the fertility of the land and the growth of vegetation - one of his epithets was exactly the "Granary of Tatenen» - and it was precisely this aspect that was symbolized by the modius in the Roman iconography of Sarapis. In spite of his chthonian definition, Ptah also gained solar connotations when he became equated with Shu - the Heliopolitan god of light and divine utterance - reminding the identification between Sarapis and Helios. But, above all, Ptah was the supreme god, creator of all living things, the universal deity gifted with solar and chthonian attributes ${ }^{84}$. Together with Osaripis, his chthonian manifestation, this god provided the nuclear elements for the cult of Sarapis.

\section{THE UNIVERSE IN SYMBOLS: THE IMPACT OF THE HERMETIC PARADIGM}

Accordingly to the heterogeneous community that created it, the Hermetic paradigm used a system of symbols and metaphors that combined key-elements taken from the Greek, Egyptian and Chaldean traditions in order to produce a philosophic discourse. The most important fact to retain about the Hermetic view of the world is the deep bond between man, taken as a microcosm, and the world, the macrocosm, with all its stars and

\footnotetext{
${ }^{83}$ Cf. HORNUNG, 2001: 53.

${ }^{84}$ SOUSA, 2011b: 168-172.
} 
planets. The combination of Egyptian and Babylonian astrological motifs performed a very important role in the creation of a new syncretic view:

Thus derives the influence of these (decans) in everything that happens (...). Overthrow of kings, revolts of cities, famines, plaques, receding of the sea, earthquakes; nothing of these, my son, occurs without their influence ${ }^{85}$.

It should be noted that, already in Pharaonic Egypt, the decans ${ }^{86}$ (the 36 stars that rule the Egyptian calendar) were connected with the concept of shai, «fate» ${ }^{87}$. Later, in Ptolemaic times, the decans figure in Egyptian temples as divine beings that have power over water and wind. They bring fertility to the fields, but they also cause illness and sudden death ${ }^{88}$. The decans also influence certain parts of the body, a belief that would play its role in Alexandrian Hermeticism, where it forms part of the correspondence between the macrocosm and the microcosm ${ }^{89}$. This theory of the decans was thus combined with the twelve signs of the Zodiac, adopted from Chaldean tradition early in the Ptolemaic Period ${ }^{90}$. This view of the Cosmos was grounded on a hierarchy of celestial spheres that ascended from the earthly realm to the Supreme Being: the zodiac (the «circle of animals»), the Sun and the Moon were closer to the Earth, followed by the sphere of the planets and, further away, by the decans that preceded the supreme sphere of the Whole ${ }^{91}$. This appealing vision gave rise to a new iconographic theme abundantly depicted in pure Egyptian canon, as well as in Greek style, and even in hybrid Greco-Egyptian style. While the famous astronomical ceiling of the Temple of Dendera magnificently showcases the monumental rendering of this new concept in Egyptian style ${ }^{92}$, the ivory astrological tablets found in Grand (France) display exactly the same concepts in Greek fashion (Fig. 3) ${ }^{93}$. Here the sky is divided into

\footnotetext{
${ }^{85}$ Book of the Thirty-six Decans, Frag. VI, in EBELING, 2007: 23.

${ }^{86}$ They are already mentioned in the Pyramid Texts, but the system of the 36 decans was not developed until the First Intermediate Period and the Middle Kingdom. The main source of information regarding them is a series of coffins from Asyut, where they are connected with the regeneration of the dead. See also in this volume the article of Telo Canhão.

${ }^{87}$ HORNUNG, 2001: 28-29. Particularly in the Third Intermediate Period and in the Late Period, decans start to be depicted on amulets, as protective deities.

${ }^{88}$ HORNUNG, 2001: 29.

${ }^{89}$ In European Modern Hermeticism the parts of the body are ruled by the planets, which seem to be a later development of this concept.

${ }^{90}$ EBELING, 2007: 22. Also MAHÉ, 1998: 60. See also MOYER, 2011: 237-238.

${ }^{91}$ MAHÉ, 1998: 62. Note that in the pharaonic Egypt such theory of the planets is lacking. See HORNUNG, $2001: 28$.

${ }^{92}$ In the central disk there are 36 decans depicted around the circumference, evoking the 360 days of the year. On the inside are twelve signs of the zodiac, together with constellations such as the Great Bear. Five planets are represented: Mercury, Venus, Mars, Jupiter and Saturn. The conjunction of planets and starts depicted in the zodiac is used to date it from about 50 B.C. ANDREU. RUTSCHOWSCAYA, ZIEGLER, 1997: 210. This depiction, now in the Louvre Museum. See also HORNUNG, 2001: 31. On the other hand Christiane Desroches-Noblecourt has argued for an Egyptian origin of the signs of the Zodiac, connecting them with the cycle of the sun and Osiris. See DESROCHES-NOBLECOURT, 2004: 308-319.

${ }^{93}$ MAHÉ, 1995: 40.
} 

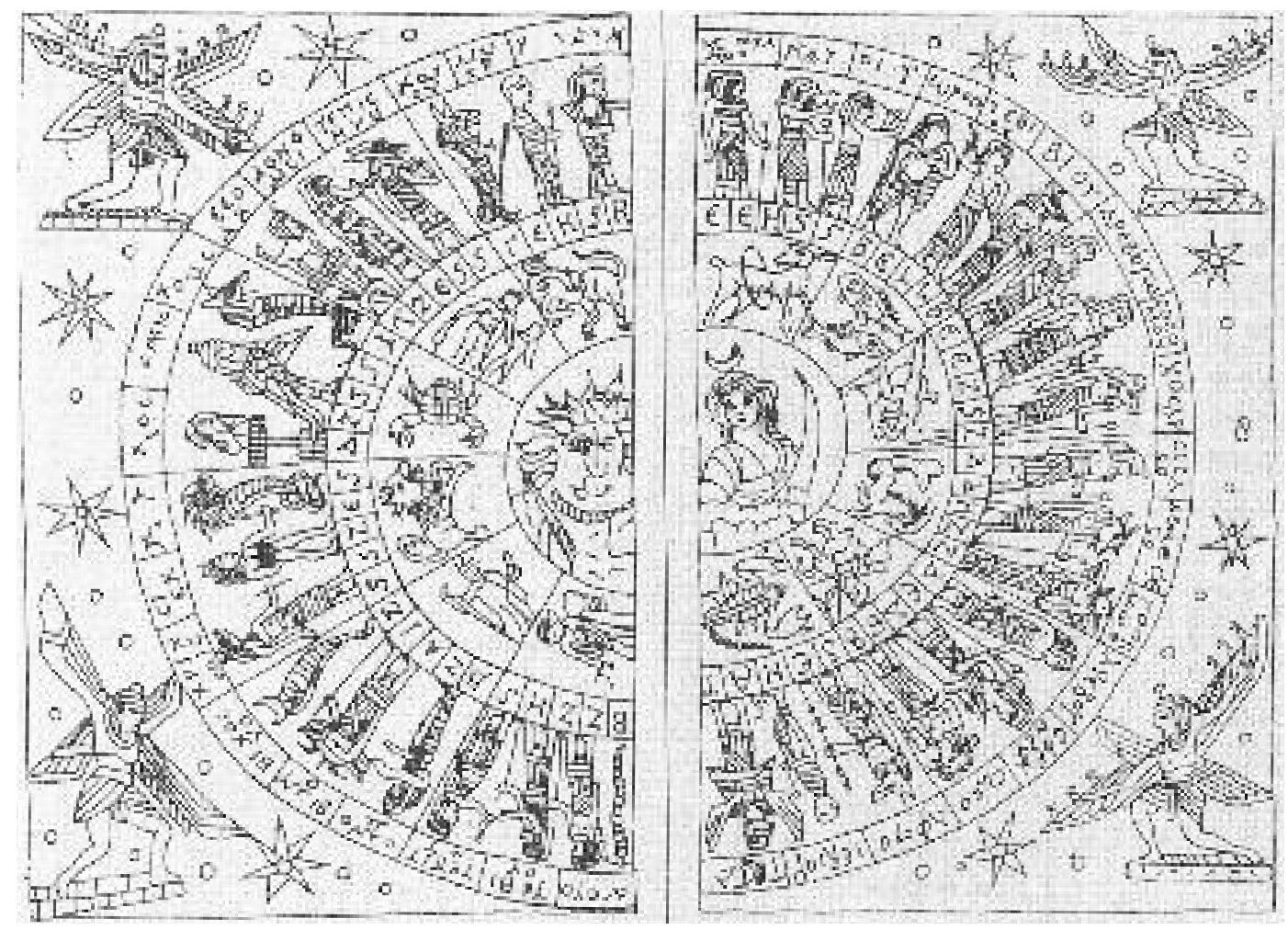

Fig. 3: Ivory astrological tablets found in Grand (Vosges).

three concentric areas: at the center of the composition stand the Sun and the Moon, followed by the twelve signs of the Zodiac and, in the third circle, the thirty-six decans which, although their names have been written in Greek, kept their Egyptian iconography, some of which depicted with animal heads ${ }^{94}$.

This same iconographic thopos figures in the Egyptian coffins from the Greco-Roman times as well. Traditionally, Nut, the Egyptian goddess of the sky, is the main figure depicted in the interior walls of the coffins. However, even when produced in Egyptian style, some coffins present a new version of this theme: the goddess is surrounded by the signs of the zodiac. We can find similar astronomical lids as early as in the Royal Sarcophagi of the New Kingdom. However, such early depictions display the decans around Nut's body, instead of the zodiac. In the Theban coffin of Soter, Nut is surrounded by the signs of the zodiac, the Egyptian goddesses of the hours and the position of the planets (noted in demotic) as well, thus indicating the horoscope of Soter, dated from 93 A.D. ${ }^{95}$.

\footnotetext{
${ }^{94}$ See KÁKOSY, 1982: 163-191; QUACK, 1995: 97-122.

${ }^{95}$ HORNUNG, 2001: 32.
} 
The expression of this «hermetic» thopos in such a multitude of styles and contexts fully attests the multicultural character of the hermetic tradition and shows that this Hellenized tradition had a strong diffusion both in Egypt, thus in purely autochthonous Egyptian circles, and in the entire Mediterranean as well. Usually seen as having little influence on local Egyptian traditions, Hermeticism seems, on the contrary, to have been widely diffused in autochthonous communities, both in the necropoleis and in the temple communities, revealing that the new cultural inputs were integrated into local traditions.

The reverse movement is also attested with Egyptian motives being adapted to purely Hellenistic contexts. In fact, Greek sources provide striking elements that showcase unexpected interations with the Egyptian tradition. This is the case of the Hellenistic statuary groups depicting a child and a goose ${ }^{96}$. Although any relevant feature of the iconography of Harpokrates is explicitly introduced in these groups, the fact is that an important corpus of Hellenistic depictions of the god Harpokrates includes the riding of a goose. In the Egyptian tradition the goose was the symbol of the god Geb (the primordial god of the earth) and it is with this reading that it appears together with Isis ${ }^{97}$. However, the goose also stood for the god Amun and, in this context, it evoked the creation of the world, which started with its gaggle. It is certainly this later reading that is illustrated in the group statues: the child (probably stands as symbol for the solar rebirth of Sarapis) «strangles» the bird in order to make it gaggle, thus making the world to become. Thus, it is a strong possibility that the anecdotic gesture depicted in the statue hides a religious «mystery».

Those examples illustrate the impact that the Alexandrian Serapeum must have had in the creation of erudite and subtle play of symbols, thus showcasing the wide diffusion of its religious paradigm in the Alexandrian cultural circles. Not to be overlooked is the diffusion of such knowledge among the Greek philosophical schools of the Serapeum. More than a philosophical school - a concept that would have been strange to the Egyptian tradition - Hermetic "paradigm» acted as a multicultural, thus «universal», corpus of erudite knowledge. As such it certainly had a profound impact on neoplatonists, especially on Porfirius and Jamblicus, but also on the emerging religious communities, such as the gnostic sects or even the Coptic monachism. It was probably the universalism of its wisdom tradition that made the cult of Sarapis the common denominator for the Alexandrian complex and rather heterogeneous religious scene. Such striking ability was seen, even for an erudite Roman as the Emperor Hadrian - also akin of the Sarapis's mysteries - as an evidence for the decadence of Alexandrian culture:

\footnotetext{
${ }^{96}$ See the article of Luísa da Nazaré Ferreira, supra in this volume.

${ }^{97}$ Such Hellenistic depictions derive from the Egyptian depictions of Nut and Geb in cosmetic spoons. See WALKER, HIGGS, 2001: 106-107.
} 
The land of Egypt, the praises of which you have been recounting to me, my dear Servianus, I have found to be wholly light-minded, unstable, and blown about by every breath of rumor. There those who worship Sarapis are, in fact, Christians, and those who call themselves bishops of Christ are, in fact, devotees of Sarapis. There is no chief of the Jewish synagogue, no Samaritan, no Christian presbyter, who is not an astrologer, a soothsayer, or an anointer. Even the Patriarch himself, when he comes to Egypt, is forced by some to worship Sarapis, by others to worship Christ ${ }^{98}$.

The priests of Sarapis were thus seen as keepers of a sacred knowledge that was probably regarded by the multicultural population of Alexandria as a «universal» tradition.

\section{ALCHEMY AS MYSTIC CRYPTOGRAPHY}

As any other Egyptian temple, it is also likely that the Serapeum could have held a «cryptographic» tradition that revolved around magical books and cult initiation. Clement of Alexandria reckons, at the beginning of the 3rd century, 36 books of Hermes carried in an Egyptian cult procession - priceless information that shows that these "philosophical» texts were used in the context of a cult ${ }^{99}$. Therefore it is nothing but natural that also the Serapeum possessed a collection of such sacred books, at the image of the autochthonous temples themselves who kept them in sacred libraries.

Indeed we know for a fact the Hermetica also present «technical» texts, most of them concerned with astrological and magical procedures aiming to achieve practical results such as healing from diseases ${ }^{100}$. In order to understand the development of this kind of texts, we have to keep in mind the reputation of the Serapeum as a healing complex where incubation took place.

The mandatory reference in Alexandrian alchemy is Zosimus of Panopolis (Akhmim), the first renowned alchemist, who lived in the late 3 rd and the early 4 th century A.D. ${ }^{101}$. Like the hermetic tractates, the texts attributed to Zosimus of Panopolis reflect the multicultural environment of Alexandria and he himself revealed a multifaceted identity: he was a Gnostic Christian but nevertheless revealed a natural affinity with the hermetic, Zoroastrianism and Mithraism doctrines. His texts reveal that he revered alongside with Hermes Trismegistus, Zoroaster, Agathodaemon, and the Persian Ostanes.

\footnotetext{
${ }^{98}$ Historia Augusta 8.

99 These books included divine hymns and royal biographies, astrological tractates, education and cult practices, laws, gods and the training of priests. See EBELING, 2007: 9.

${ }^{100}$ Deriving from temple practices and rituals, these technical Hermetica became, in medieval and modern times, the very core of alchemy and for this reason they can be properly seen as the ancestors of the modern alchemic texts.

${ }^{101}$ Other Egyptian sages were active, such as Petasius, Phimenas and Pebechius. One of the latest was Stephanus of Alexandria who lectured on alchemy in the 7th century. HORNUNG, 2001: 34. It is interesting to note that, unlike the Hermetic texts, who are attributed to a mythic author, the alchemic works are attributed to historical sages.
} 
Not surprisingly, although deriving from ancient temple practices, «technical» Hermetica reveal a strong affinity with the experimental spirit of the Alexandrian Museum. Alchemy involved complex technical and laboratory procedures seeking to achieve manipulation of the properties of matter. Alchemists look for the specific effect that planets had in the occurrence of certain diseases, aiming, on the other hand, to detect the most suitable treatments to restore the «cosmic» balance of the body, taken as a replica of the Universe. The correspondences between the planets and the plants provided the bases for the supposed therapeutic effects of the latter ${ }^{102}$. Minerals and metals were also associated with the decans, creating a bridge between astrology, alchemy and medicine ${ }^{103}$. In Hermeticism, these Egyptian notions were combined with the Greek idea of heimarmene, «fate», or ananke, «destiny» ${ }^{104}$. This pharmacology combined astrology with 'botanical' and mineral knowledge, which could only have been possible in the context of the Alexandrian Museum.

As the nature of the universe and human nature had a strong affinity with each other, the alchemist longed for accomplishing the transmutation of the four elements in order to produce a fifth element, that of the aether or spirit, which held in itself the secret of life. In modern times, this work was symbolized in the production of the Philosophical Stone, or Lapis, the quintessence that resulted from the harmonious union between the elements of matter and spirit ${ }^{105}$. There is debate over the extent to which the theory of the four elements did exist in ancient Egypt ${ }^{106}$. Although reference to physical elements, such as air, light or water, can figure in the funerary texts, only seldom are they quoted together. In fact only one of such attestations is known to us:

Words spoken by Osiris, the foremost of the Amentit, the great god: offerings are given to him in Abidos. He gives light (fire), bread, breeze and water to the Osiris Mistress of the House, songstress of Amun-Re, Shedsutauepet ${ }^{107}$.

Although remarkable, this allusion can hardly be taken as an evidence for an Egyptian theory of the four elements. While most of the Egyptian sources do not give us a clear indication in this respect, Greek sources are, on the contrary, quite prolific. Greek influence in the adoption of the four elements seems more likely.

The oldest known alchemical texts already reveal the concern to synthesize quicksilver and precious metals. Although rooted in the Hermetic tradition, alchemic works are not

\footnotetext{
${ }^{102}$ EBELING, 2007: 22.

${ }^{103}$ HORNUNG, 2001: 30.

${ }^{104}$ HORNUNG, 2001: 30.

${ }^{105}$ SIMON, 2004: 169.

${ }^{106}$ HORNUNG, 2001: 40.

${ }^{107}$ Inscription 1 (lid), coffin of Shedsutauepet (A.110) in the Sociedade de Geografia de Lisboa.
} 
philosophical discourses and they seem strongly akin to the Greek context of Alexandria. The standard alchemic work, Physica kai Mystika of Pseudo-Democritus, offers instructions on the imitation or preparation of precious metals from base ones. Gold or the Philosopher's Stone is to be prepared from lead: success will be achieved through a process by which the metal turns successively black, white, yellow and red ${ }^{108}$.

It is important to state that such «laboratorial» activities were also performed in autochthonous temples of Greco-Roman Egypt ${ }^{109}$. Far from the Hellenized Alexandrian alchemists, a sacred «laboratory» is found in the Ptolemaic temple of Edfu. Its texts, carved under Ptolemy VI, include a number of formulas for preparing incense and ointment for the divine statues. Various mixtures were to be heated and reheated at two-days intervals:

when it is hot, add 2 kite ( 1 kite $=9 \mathrm{~g}$ ) of each of all kinds of precious stones, namely, of gold, silver, genuine lapis-lazuli, genuine red jasper, genuine green feldspar, turquoise, genuine faïence, and genuine carnelian, crumbling each of these especially fine ${ }^{110}$.

Also in the Greco-Roman temple of Hathor at Dendera, a special chamber, the «House of Gold», was designed for the preparation of sacred substances used in worship. The texts mention Thoth as the divine «alchemist» responsible for these activities. The goddess Hathor says: «Receive these costly materials of the mountains to carry out every work in the House of Gold» ${ }^{111}$.

Alexandrian alchemists and Egyptian priests of Greco-Roman Egypt were seemingly working under a similar inspiration. In fact, long before Greco-Roman times, we know for a fact that the use of gold and other precious materials in Egypt performed magical purposes, especially in the funerary context. The «House of Gold», the royal funerary chamber, does not necessarily indicates that such room was filled with gold but rather that a magical phenomenon was supposed to occur: the identification of the Sun (materialized in gold) and the Pharaoh that attested his transformation in an immortal being ${ }^{112}$. The same reading of the magical purpose of gold can be detected in alchemy ${ }^{113}$.

The equation between the creation of gold and the inner transformation is already attested in Pharaonic Egypt. For the Egyptians, minerals were living entities. Lapis-lazuli «grows» like a plant ${ }^{114}$ and gold «emerged» (besi) from the Nun, in the depths of the earth.

\footnotetext{
${ }^{108}$ EBELING, 2007: 25.

${ }^{109}$ EBELING, 2007: 17. Also HORNUNG, 2001: 35.

${ }^{110}$ HORNUNG, 2001: 37.

111 (Dendara VIII 132, 3-8), in HORNUNG, 2001: 37.

112 AUFRÉRE, 1991: 376-390.

113 AUFRÉRE, 1991: 362-366.

${ }^{114}$ Pyramid Texts, $\$ 513$.
} 
The same verb, besi («to emerge» or «to introduce»), had an important religious meaning as well, since, in Pharaonic times, it stood for the initiation of the king (or priest) in the divine realm. Through initiation, the Pharaoh was transformed into a divine being, thus achieving immortality. This event was clearly equated with the almost miraculous emergence of gold from the darkness of the earth ${ }^{115}$. Not surprisingly, this phenomenon was particularly meaningful for the Memphite tradition, where the priests of Ptah presided over the work of goldsmiths, surely involving the technical process of their work within a symbolic framework ${ }^{116}$.

It is already clear to the reader that, at least in its later use, the 'laboratorial' alchemical language consisted in a ciphered allegory for an inner or «mystical» transformation. In the context of alchemy, mystical experiences are allegorically translated into chemical language to cover a Gnostic redemptive path ${ }^{117}$. It should be noted that the use of allegory is by no means stranger to the spirit of Alexandrian culture ${ }^{118}$. In many ways, the allegorical interpretation provided a semantic «translation» of the texts and revealed, through the philosophical approach, the true hidden meaning of the text. The distinction between a literal sense of reality and a deeper, hidden meaning, which can be accessed through its allegorical interpretation, is a distinctive feature of Alexandrian culture and it can be seen as the intellectual ground of its multiculturalism.

The alchemical metaphors used a similar process. Allegorical language is composed of images borrowed from laboratory techniques in order to keep the secrecy of their message untouched. In this respect the discourse of alchemy clearly betrays its Egyptian background and takes further on the same cryptographic process that was being developed in the autochthonous temples. The allegorical interpretation of alchemy aims to conceal its message rather than to reveal it, thus showcasing the same desire of self-segregation detected in cryptographic and cultic texts. While trying to unravel the secrets of nature (pretty usual attitude for the scholars of the Museum), alchemist aimed to preserve its sacredness by keeping them secret. It is precisely in this pursuit for secrecy that alchemy reveals its Egyptian roots which always have been eminently esoteric ${ }^{119}$.

\footnotetext{
115 SOUSA, 2009: 32; See also KRUCHTEN, 1989: 150.

${ }^{116}$ AUFRÉRE, 1991: 362-366.

${ }^{117}$ HORNUNG, 2001: 40.

${ }^{118}$ The translation of the religious texts from other traditions did not occur only for the sake for knowledge from the part of the Greek sages. It served practical purposes, especially to the ethnic community which they belonged to: the translation of the biblical texts has to be related with the illiteracy of the Alexandrian Jews on Hebrew as well. However, this «translation» process evolved into a deeper level, when an allegorical interpretation took place over these translated texts, as if the Greek translation would be regarded as insufficient to reach the true meaning of the texts.

${ }^{119}$ In order to preserve its sacredness the text must conceal it following a distinctive feature of the Egyptian sacred texts. LOPRIENO, 2001: 30-32.
} 
The need for secrecy around the alchemical opus is better understood when we attend to the equivalence established between alchemic transformation and the myth of Osiris. In fact, Zosimus of Panopolis explicitly refers to the alchemical process as an «Osirification» ${ }^{120}$. The alchemical process thus appears to be grounded in the mythic archetype of death and resurrection of Osiris: the corpse of the king, Osiris, undergoes a decaying process (the nigredo) and engenders his heir, Horus, in whom he will live again.

Mummification was the inspiration for the alchemic quest ${ }^{121}$ : death triggered the decomposition process, the nigredo, but sage manipulations of the corpse through chemical operations culminated in spiritual rebirth. When seen in this light, the alchemic opus should be concluded with a ceremony somehow equivalent to the Egyptian Opening-ofthe-mouth funerary ritual, which allowed for the rebirth of the deceased ${ }^{122}$. During this ritual, a heart scarab is often positioned over the mummy to symbolize the awakening of the deceased and his rebirth ${ }^{123}$. Although in Greco-Roman Egypt such objects were largely in disuse in mummification, as many other aspects of the Egyptian funerary beliefs, their symbolism might have been transferred to the earthly life ${ }^{124}$. It is therefore a possibility that their symbolism was now seen at the light of the inner transformation that occurred in the heart of the alchemist, the true Lapis, as the concluding result of the opus ${ }^{125}$. The modern quest for the Philosophal Stone, the «stone that is not a stone, a precious substance of no value in many ways and report, known and familiar to all $»^{126}$, should then be seen as a later reminiscence of the Egyptian heart scarab, understood as metaphor for the awakening and illumination of the heart, i.e., the divine mind ${ }^{127}$.

This gnostic «osirification» should lead the alchymist to a spiritual rebirth, leading him to see god and to unveil the ultimate nature of things. Although the laboratorial quest may seem conspicuously absent, a similar process of transformation was expected to occur during the initiation to the cults of Isis and Sarapis described in Apuleius' Asinus Aureus. As the alchemic initiates, Lucius witnesses a change not only of his body, but also of his mind

\footnotetext{
${ }^{120}$ HORNUNG, 2001: 39.

${ }^{121}$ Crypts dedicated to Osiris reflect the mortuary aspect of the late Egyptian temples. FINNESTAD, 1997: 214. Such «Osirian» reading of the alchemical process is therefore based on identification between the laboratorial processes of alchemy and the mummification ritual. See ASSMANN, 2002: 409-411.

${ }^{122}$ Such ritual is described in the Book of Thoth where the neophyte is the object of a ritual similar to the Opening-of-themouth. See JASNOW, ZAUZICH, 2005: 59.

${ }^{123}$ One should here recall the important Egyptian symbols for the heart: the heart amulet and the heart scarab. See SOUSA, 2011a: 37-44.

${ }^{124}$ Indeed in Ptolemaic times, the heart amulet was mainly used as a symbol of the divine children and was often depicted in Egyptian temples built during this period. See SOUSA, 2010: 81-91.

${ }^{125}$ For the pharaonic symbolism of the cardiac amulets see SOUSA, 2011a: 37-45.

126 SIMON, 2004: 154.

${ }^{127}$ Such change of interpretation can be witnessed in the Egyptian iconography of the heart amulet as well, since in the Ptolemaic Period, the heart amulet is no longer used in the funerary contexts, but in close association with the cult of Horpakhered, thus as symbol of enlightment. SOUSA, 2010:81-91. See also SOUSA 2011a:10, 48-49.
} 
and life as opposed to the traditional hero of the Hellenistic novels who, at the end of many vicissitudes, has not changed ${ }^{128}$.

One could expect that the initiation to the Alexandrian cult of Sarapis could involve a longer and much more demanding period of learning, where alchemic knowledge would take a very important part of the priestly training, as it happened in the contemporary autochthonous temples. Although following a model of priestly initiation well known in the Pharaonic tradition, the «mystery» cults of Isis and Sarapis developed in Alexandria obviously present associations with the Eleusian mysteries as well. As we have seen, particularly in the context of the Alexandrian Serapeum, the Eleusian mysteries and the Osirian myth were the object of close association.

Hellenized cults of Isis and Sarapis were adopted by and necessarily adapted to the urban culture of the Roman Empire. Such version of inner regeneration transcended completely the borders of Egypt and spread out through the Roman Empire propelled by the diffusion of the cults of Sarapis and Isis as far as the shores of the Atlantic. Perhaps Panóias, Vila Real, Portugal, the Roman complex dedicated to Sarapis, witnessed similar rituals but it would be difficult to expect in such remote sanctuary the same degree of complexity that could have been found in the Serapeum of Alexandria. And yet, together with a striking symbiosis with local Neolitic traditions, it displays - however simplified they might have been - the key-features of a Serapeum.

\section{CONCLUSION}

All sectors of Egyptian sociocultural life underwent change during the Ptolemaic and Roman Periods: economy, government, demography, religion. Granted, the social and cultural contexts had always been changing, and the temples had continually adapted. Political and historical studies on this period stress the openness of the cultural and sociological milieu of Ptolemaic Period as opposed to the increasing tensions emerging in Egyptian society during Roman domination, most of them related to the definition of citizenship. Cultural identity is a much broader concept, involving social practices and cultural beliefsystems. Adopting Egyptian beliefs does not mean do became Egyptian, and most certainly many of the new settlers that adopted mummification as burial practice did not hesitate to define themselves as Greek or Roman citizens. The same probably could be said of the Egyptian priests that wrote their texts in Greek.

The religious scene during the Ptolemaic and Roman Periods was diverse and complex. Egyptian tradition existed side by side with non-Egyptian traditions, or mingled with them to produce new gods, new cults, and new cultic communities, especially in Memphis

\footnotetext{
${ }^{128}$ FILORAMO, 1999: 148.
} 
and in the cities newly founded such as Alexandria, Antinoopolis and others. Important Ptolemaic and Roman temples existed in all major towns dedicated to foreign deities - Jewish religion had been practiced in Egypt since the 6th century B.C. and in the Roman Period many Christian churches were established. The patterns of interaction and relationship between the various cults are difficult to grasp ${ }^{129}$.

Starting as a political «tool» used by the Ptolemaic rulers, Hellenization of the Egyptian cults aimed at the integration of the multicultural society and had important consequences both in the affirmation of the universal character of the dynasty and in the diffusion of the autochthonous beliefs, particularly those related to the afterlife, into a wider multicultural audience. Religious and literary sources suggest that the limits that once distinguished Egyptian cultural tradition from the Greco-Roman thought became more and more blurred up to the point that the classification of a particular text or artifact as «Egyptian» or «Greek» can be a difficult if not impossible task ${ }^{130}$.

At first, the Hellenization of the Egyptian tradition involved the adoption of Greek language and iconography but it progressed into more subtle and deeper ways by the adoption of the Greek language and the philosophical methods for the very expression of the Egyptian theology and wisdom. The effectiveness of such process could only have been possible thanks to the increasing «demotization» of the Egyptian culture in the Greco-Roman Period: in fact Pharaonic legacy was already under «translation» into Demotic language when the Macedonians installed themselves in Egypt. This phenomenon, detectable in the local intellectual centers, particularly in the temple of Ptah in Memphis, launched the bases for the Hellenization of the Egyptian tradition in the context of the newly founded city of Alexandria.

Attending to the high degree of the cultic and magical knowledge revealed in hermetic texts and iconography, it does not seem excessive to admit that they should be attributed to a multicultural community composed of Hellenized Egyptian priests and Greek scholars as well who were carrying out much more than just a process of translation of texts. They were expressing the contents of the Egyptian theological thought, not only in Greek language or images, but also recurring to Greek philosophical concepts, myths and methods. During this process, the Egyptian background might seem to be lost in translation. Nevertheless, Hermetic texts must be properly seen as the result of an autochthonous and multicultural tradition born from the demotic background of the local Egyptian temples and fully matured in Alexandria: demotic in content, Greek in language and discourse, Hermeticism longed for universalism, thus in perfect alignment with the multicultural trend of ancient Alexandria. Adopting elements and images from other (familiar) traditions, such as the Persian or the Jewish, it not only mirrored the richness of the cultural influx that charac-

\footnotetext{
${ }^{129}$ FINNESTAD, 1997: 234.

${ }^{130}$ See the article of Kyriakos Savvopoulus, supra in this volume.
} 
terized Ptolemaic Egypt as it fully expressed its own search for universalism ${ }^{131}$. Possibly for this reason, it seems that interaction with the Egyptian demotic tradition of the local temples and necropoleis has originated a constant influx in both directions with hermetic features being also integrated in demotic texts.

Once established, Hermeticism do seems to have truly played the role of a paradigm for local autochthonous cult centers as well, thus irradiating the new multicultural corpus of texts and knowledge to all over Egypt. Notwithstanding differentiations among the various categories of Egyptian priests, they acted in many respects as a socioreligious group and they met regularly in synods ${ }^{132}$, which could make easy the diffusion of such ideas and texts. Once formulated in Greek or demotic, the ideas of the Hermetic "paradigm» revealed to be perfectly compatible both with the Alexandrian cults and with the traditional Egyptian cults as well. One could say that Hermeticism could have been seen in Antiquity as a corpus of concepts working as a "paradigm», a bulk of erudite knowledge that was able to inspire the intellectual activity of Greek Alexandrian philosophers, Hellenized priests of the Alexandrian temples and Egyptian priests of the autochthonous temples.

This multicultural «paradigm» combined elements from all the ancient traditions and originated a great diversity of textual and iconographical expressions - from philosophical discourses to tomb decoration. In this scenario, the Alexandrian Serapeum emerges as the cradle of this new multicultural tradition. With its roots grounded on the Egyptian wisdom, the sages of the Library-Daughter expressed this new tradition in Greek or demotic philosophical discourses. In spite of the Hellenistic features of its gods, the cult performed at the Serapeum involved a ritual initiation grounded on a multicultural worldview, the hermetic "paradigm», which preserved quite remarkably its Egyptian background and was encoded on alchemic procedures aiming at the awakening of the neophyte. In spite of and perhaps because of that, the tradition forged in the Alexandrian Serapeum would be in use by a wide multicultural population and would reach territories far beyond the borders of Egypt itself, eventually leading to the diffusion of these cults through the entire area of the Mediterranean.

The difussion of the Alexandrian cults thus involved a complex set of notions related to temple architecture, ritual initiation and knowledge - the latter provided by philosophical texts (such as those later collected in the Corpus Hermeticum) while ritual initiation would be attained through training on magical procedures (encoded in alchemical and magical texts).

Although clearly grounded on a genuine Egyptian conceptual framework, hermetic paradigm must be seen as the result of the cultural elite, which, regardless of their ethnic or

\footnotetext{
${ }^{131}$ EBELING, 2007: 30.

${ }^{132}$ During a long period under the Ptolemies, they were expected to meet in annual conventions to discuss with representatives of the state matters pertaining to politics and cultus. FINNESTAD, 1997: 228.
} 
cultural origin, and even their priestly or profane duties, could look into Hermeticism as a source for knowledge and wisdom. It is difficult to know how aware ancient writers, whether Greek or Egyptian, were in regard to the definition of Hermeticism as a philosophical tradition on its own. Such definition would be superfluous, at least to the Egyptian sages. Perhaps it is this typically open Egyptian attitude towards knowledge that explains the huge success of Hermeticism in the Hellenistic world and the adoption of its elements by different philosophical schools and even by different (and antagonist) religious sects.

Identity in Greco-Roman Egypt and particularly in Alexandria is a multicultural phenomenon. The «bilingual» culture of the Ptolemaic Period evolved more and more progressively into the constitution of a global cultural paradigm, Greek in expression, but multicultural in content. The Alexandrian Serapeum fully expressed this bilingual civilization both through its cult and its culture.

Much research is still needed in order to have a clearer picture on the interaction of the Egyptian autochthonous culture with the Greco-Roman thought. The fact is, even after the complete destruction of the Alexandrian Serapeum, its legacy has been able to survive. Both Alchemy and Hermeticism would reveal themselves as two long last traditions that would mock the frontiers of space and time: they would be able not only to widespread their influence long beyond the borders of Egypt as they would have an important role to play in the "awakening» of knowledge both in the medieval Islamic world and in modern Europe. 